Historic, Archive Document

Do not assume content reflects current scientific knowledge, policies, or practices. 



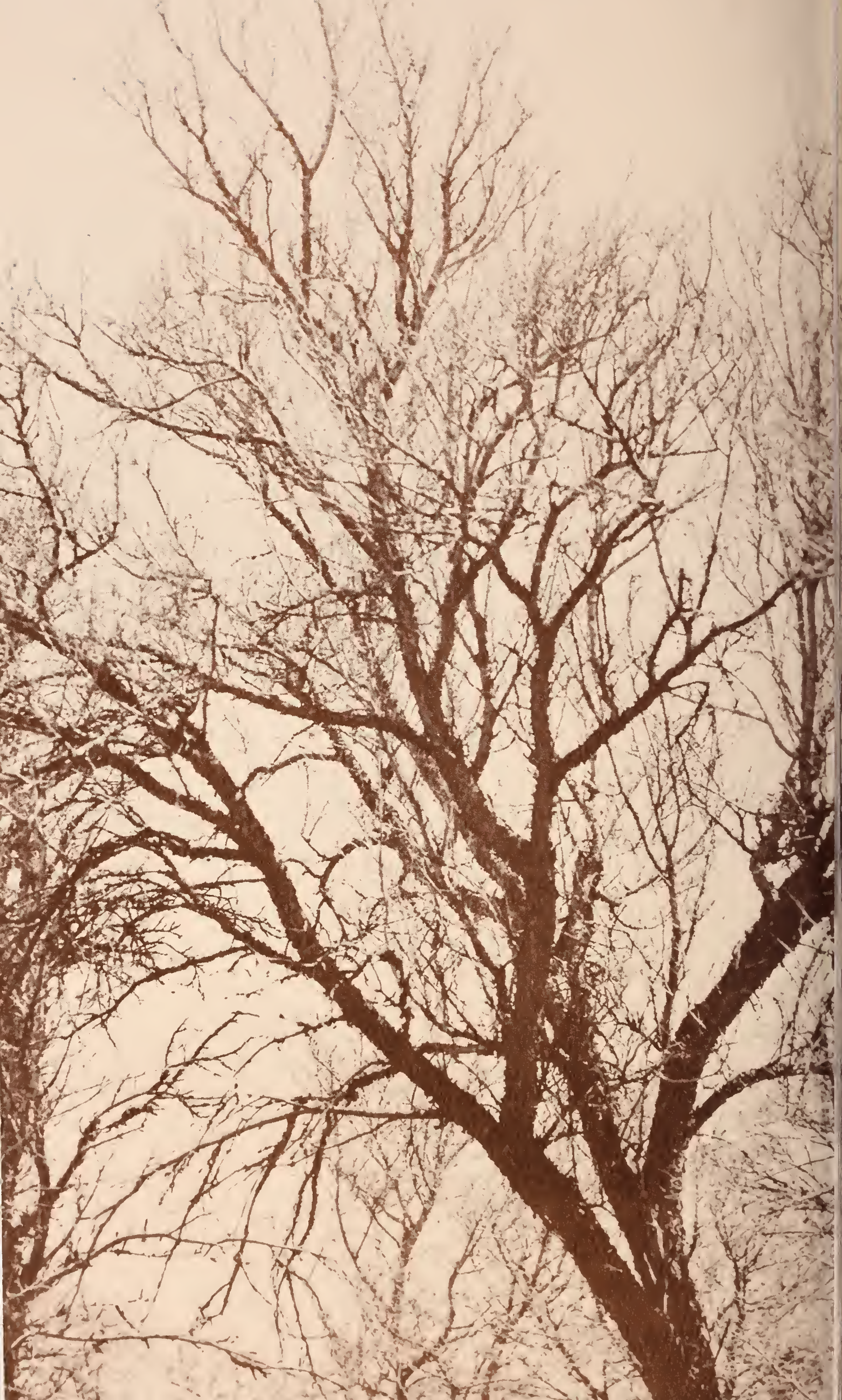




\section{INSECTS AFFECTING \\ IMPORTANT NATIVE SHRUBS OF THE NORTHWESTERN UNITED STATES}

\section{Malcolm M. Furniss and William F. Barr}

(Published with the approval of the Director of the Idaho Agricultural Experiment Station as Research Paper No. 7466)

INTERMOUNTAIN FOREST \& RANGE EXPERIMENT STATION

\section{Forest Service}

U.S. Department of Agriculture

Ogden, Utah 84401

Roger R. Bay, Director 


\section{THE AUTHORS}

MALCOLM M. FURNISS is leader of a research work unit on coniferous and browse plant insects located at the Forestry Sciences Laboratory, Moscow, Idaho. He has studied insects on shrubs in relation to big game ranges since 1961 and has for a longer time studied ecology of bark beetles in forest trees. He has published extensively on their ecological relationships, bionomics, and pheromones.

WILLIAM F. BARR is Professor of Entomology, University of Idaho, Moscow, Idaho. He has studied insects on desert shrubs, principally in Idaho, since 1955 and also has worked on the biological control of weeds. He has published extensively on the taxonomy of buprestid and clerid beetles. 


\section{ACKNOWLEDGMENTS}

Much of the information presented here was obtained from specialists, who provided valuable unpublished data and references. In particular, we thank F. W. Stehr, Michigan State University, who provided information on Malacosoma spp., and D. W. Davis, Utah State University, who provided the information on Hemileuca. We are also grateful to R. C. Bechtel, Nevada Department of Agriculture (collections of Hemerocampa vetusta gulosa (Boisduval) and references to Apterona crenulella (Bruand)); H. H. Keifer, California Department of Agriculture (identification of Aceria kraftella Keifer); J. A. Powell, University of California (information on Ethmia discostrigella (Chambers)); and D. J. Williams, British Museum (identification of Lecanium cerasifex Fitch). R. I. Sailer, R. W. Hodges, E. L. Todd, and D. M. Weisman of the USDA Insect Identification Branch provided valuable references and authoritative identification of other taxa. We appreciate the helpful reviews of the manuscript by R. L. Furniss, Portland, Oregon, and J. A. Schenk and A. R. Gittins, University of Idaho. 


\section{ABSTRACT}

Information is presented on insects and mites associated with important shrubs native to the $\mathrm{Pa}-$ cific Northwest. Forty-three insect species or insect groups and one mite species are discussed with emphasis placed on their geographic range, hosts, type of damage, appearance and habits, life cycle, and natural control. The orders of insects and mites represented are Coleoptera (beetles), Diptera (flies), Hemiptera (true bugs), Hymenoptera (ants), Lepidoptera (moths and butterflies), Thysanoptera (thrips), and Acarina (mites). A host plant index to the following genera is provided: Acer, Alnus, Amelanchier, Arctostaphylos, Artemisia, Atriplex, Betula, Ceanothus, Cercocarpus, Chrysothamnus, Populus, Prunus, Purshia tridentata, Quercus, Ribes, Rosa, Salix, Sambucus, Symphoricarpus, Ulmus. 


\section{CONTENTS}

Page

INTRODUCTION . . . . . . . . . . . 1

IMPORTANT INSECTS . . . . . . . . . . 3

COLEOPTERA: Beetles.......... 3

Buprestidae: Flatheaded or Metallic

Wood Borers ......... 3

Acmaeodera spp. . . . . . . 3

Agrilus spp. . . . . . . . . 4

Anthaxia spp. . . . . . . . 6

Dicerca horni Crotch and

D. pectorosa LeConte. . . . 7

Cerambycidae: Roundheaded Wood

Borers or Longhorned Beetles . . . 7

Crossidius spp. . . . . . . . 7

Desmocemus spp. . . . . . . 9

Chrysomelidae: Leaf Beetles . . . . 10

Altica spp. . . . . . . . . 10

Disonycha spp. . . . . . . 11

Trirhabda spp. ........ 11

Curculionidae: Snout Beetles or Weevils 13

Rhynchites bicolor (Fabricius). . 13

Sternochetus Zapathi (Linnaeus) . 14

Scolytidae: Bark Beetles...... 16

Chaetophloeus heterodoxus

(Casey) (=Renocis) . . . . 16 
DIPTERA: Flies . . . . . . . . 18

Cecidomyiidae: Gall Midges . . . . . 18

Mayetiola sp. (=Phytophaga) . . 18

Tephritidae: Fruit Flies . . . . . 20

Eutreta, Procecidochares, and

Aciurina spp. . . . . . . 20

HEMIPTERA: True Bugs . . . . . . . . 22

Pentatomidae: Stink Bugs . . . . . . 22

ChZorachroa sayi (Stäl) . . . . 22

HOMOPTERA: Aphids, Leafhoppers,

Planthoppers, Scale Insects, and Allies. . 24

Coccidae: Soft Scales . . . . . . . . 24

Lecanium cerasifex Fitch . . . . 24

Diaspididae: Armored Scales . . . . . 26

Lepidosaphes uImi (Linnaeus) . . . 26

Ortheziidae: Ensign Scales . . . . . 28

Orthezia artemisiae Cockerell . . 28

HYMENOPTERA: Ants, Bees, Sawflies, Wasps, and Allies . . . . . . . . 28

Formicidae: Ants . . . . . . . . 28

Pogonomyrmex occidentalis

LEPIDOPTERA: Moths, Butterflies, Skippers. . 29

Ethmiidae: Ethmiid Moths . . . . . 29

Ethmia discostrigella (Chambers). 29

Gelechiidae: Gelechiid Moths . . . . 30

Aroga websteri Clarke . . . . 30

Filatima sperryi Clarke .... . 32

Gelechia mandelza Busck. . . . . 33

Geometridae: Measuringworms or

Loopers . . . . . . . . . . . 34

Anacamptodes clivinaria

profanata (Barnes and

McDunnough) 
Lasiocampidae: Tent Caterpillars . . . . 37

MaZacosoma spp. . . . . . . . . . 37

Lymantriidae: Tussock Moths . . . . . . 42

Hemerocampa vetusta gulosa

(Boisduva1) . . . . . . . 42

Nymphalidae: Brushfooted Butterflies . 45

Nymphalis antiopa Linnaeus . . . . 45

N. califormica (Boisduval) . . . . 47

Psychidae: Bagworm Moths....... 50

Apterona crenulelza (Bruand)

form helix....... . 50

Saturniidae: Giant Silkworm Moths . . 52

Hemileuca spp. ........ 52

Tortricidae: Leafroller Moths . . . . 54

Synnoma Zynosyrana Walsingham . . . 54

THYSANOPTERA: Thrips ........ . . 55

Thripidae: Common Thrips . . . . . 55

Frankliniella occidertalis

(Pergande) ....... . 55

IMPORTANT MITES . . . . . . . . . 57

ACARINA: Mites and Ticks . . . . . . 57

Eriophyidae: Gall Mites . . . . . . 57

Aceria kraftelza Keifer... . . 57

HOST PLANT INDEX . . . . . . . . . . . . . 59 



\section{INTRODUCTION}

The shrubs considered here are primarily species native to the Pacific Northwest, although they may also grow elsewhere. ${ }^{1}$ They are deciduous woody plants, generally less than 10 feet tall, but some species may reach the size of small trees. These shrubs are commonly associated with the forest, either along its margins, within burns, in the understory, or along watercourses. Some, such as Artemisia and Chrysothomnus, grow in semiarid areas. Shrubs are an important ecological element, especially as food and shelter for wildlife--many are called browse plants. Their early presence after fires aids in stabilizing the watershed and is important to the succession of vegetation and the restoration of site productivity. In spite of their value, shrubs have received less study than other plant groups, ${ }^{2}$ and similarly, the insects that utilize them as hosts have not been studied extensively.

The insect species discussed are characteristically restricted to certain kinds of plants. Furthermore, only certain parts of the host plant are usually infested by a particular insect.

Defoliation is perhaps the most common and conspicuous type of damage. Less evident damage may occur to the stems and to the reproductive parts at all stages leading to seed formation. Although root damage is known to occur, little

${ }^{1}$ C. Leo Hitchcock, Arthur Cronquist, Marion Ownbey, and J. W. Thompson. Vascular plants of the Pacific Northwest. Univ. Wash. Pub1. in Biology, Vo1. 17. Part 2, Salicaceae to Saxifragaceae, 597 p. (1964); Part 3, Saxifragaceae to Ericaceae, 614 p. (1961); Part 4, Ericaceae through Campanulaceae, 510 p. (1959); Part 5, Compositae, 343 p. (1955). $1955-1964$.

Doris W. Hayes and George A. Garrison. Key to important woody plants of eastern Oregon and Washington. U.S. Dep. Agric., Agric. Handb. 148, 227 p. 1960.

${ }^{2}$ Wildland shrubs--their biology and utilization. USDA For. Serv. Gen. Tech. Rep. INT-1, 494 p. 1972. 
information about it has been gathered. Infestation of stems by certain insects such as the poplar-and-willow borer may actually stimulate sprouting by older (taller) willow plants, thus increasing their availability to game animals; however, the long-term effects of such infestations have not been determined. More commonly, infestation reduces growth and vigor (e.g., gall midges) or kills the affected plant or some of its branches (e.g., flatheaded woodborers).

The possibility that insects such as juice-sucking bugs act as vectors of diseases of browse plants has received little study but merits consideration in baffling instances of stand decadence where evident causes are lacking. Insects, through their specificity, also influence succession by affecting species composition. It is hoped that this specificity may be utilized to rid areas of less desirable shrubs in favor of others. Besides affecting plant hosts, some insects have a toxic or repellent effect on animals that ingest them. These include caterpillars with urticating hairs and stink bugs which secrete a noxious fluid.

To seek better understanding of the relationships between insects and native shrubs, we have conducted surveys and limited studies of the relevant species. These studies have been supplemented with information from other entomologists (See Acknowledgments) and from the literature. We have selected for inclusion here only those insects about which useful information is presently available. Some species that are undoubtedly important, such as the rootfeeding Curculionidae and Scarabaeidae, and the leaf- and stem-feeding Cicadellidae, have thus been omitted. This publication is intended as an initial step toward a comprehensive guide for forest, range, and wildlife resource managers and researchers. Information for such a guide, however, will require greatly expanded research on both the plants and the insects infesting them.

The text is divided into two parts: (1) A discussion of insects in alphabetical order; and (2) a host index.

A standardized format includes scientific and common names; geographic range; hosts; description of damage; appearance and habits; life cycle; and natural control. We have omitted applied control recommendations; those that exist can be sought in the cited literature or, preferably, from a University, County extension agent, State forestry office, or from the forest pest control staff of a Forest Service regional office. 


\section{IMPORTANT INSECTS}

\section{COLEOPTERA: BEETLES}

\section{Buprestidae: Flatheaded or Metallic Wood Borers}

\section{Acmaeodera spp.}

RANGE. Widely distributed in the United States and southerm Canada. A great majority of the species occurs in the southwestern desert areas and the chaparral belts of the Westerm States.

HOSTS. Many species of broadleaf trees and shrubs. Host specificity is common. Representative browseland hosts include species of Cecnothus, Cercocarpus, Quercus, Arctostaphylos, Rosa, and Purshia tridentata (Pursh) DC.

DAMAGE. Larvae bore in the wood of roots, stems, and branches of the hosts. Their activity is usually confined to dead or injured portions. No extensive killing of host plants has been reported.

APPEARANCE AND HABITS. No information on the eggs is available. Larvae are typical flatheaded borers. The first expanded body segment lacks rugosities but has a single median groove or line. Larvae are white or cream colored, somewhat chunky in appearance, and up to one-half inch long. The pupa is found in a cell at the ending of a larval boring tunnel near the bark surface. Adults are somewhat triangular or cylindrical in shape and frequently have characteristic colorful markings. Adults of most species can be found on the host plant where they feed on tender leaves or flower parts, but they also commonly occur on nonhost flowers where they feed on pollen and mate.

LIFE CYCLE. The cycle is generally regarded to take 2 years. The adult stage is seasonally specific. Larvae generally oveminter. 
Barr, William F. 1971. Family Buprestidae. P. 83-86, in: Hatch, Melville H. The beetles of the Pacific Northwest. Part V. Univ. Wash. Publ. Biol., Vol. 16.

Burke, H. E. 1917. Flatheaded borers affecting forest trees in the United States. U.S. Dep. Agric. Bull. 437, 8 p.

Fal1, H. C. 1899. A synopsis of the species of the genus Acmaeodera of America north of Mexico. J. N.Y. Entomol. Soc. $7: 1-37$.

\section{Agrilus spp.}

RANGE. Widely distributed in the United States and southerm Canada. A large number of species have been described. Species are not as well represented in the browse plant areas of the Western United States and Canada as in other areas, however.

HOSTS. Many broadleaf trees and shrubs; some species are host specific. Browse plants frequently attacked include species of Chrysothamnus, Arctostaphylos, Salix, Betula, Alnu and Quercus.

DAMAGE. Damage to the host plant is usually negligible, but larvae can girdle and kill individual branches and twigs (fig. 1).

APPEARANCE AND HABITS. The flattened or scalelike eggs are deposited on bark of the host plant singly or in small clusters, and are usually covered with a protective, varnishlike secretion. They are difficult to find. The larva is elongate and up to $25 \mathrm{~mm}$ long. Only the first body segment is expanded; it bears a median groove. The last body segment terminates in a pair of conspicuous chitinized spines The mature larvae usually mine the inner bark and wood and may produce a spiraled boring around twigs, branches, and trunks of living or dead trees and shrubs. Occasionally, they may bore exclusively in the wood of stems and roots of shrubs. The pupa is about half the length of the mature larvi it is creamy white and characteristically slender. Pupation takes place in the cell constructed by the larva in the wood. Adults are slender and cylindrical. They are blue to coppery iridescent, and frequently have pubescent spots or stripes. They are usually found on the host plant, where they may feed 


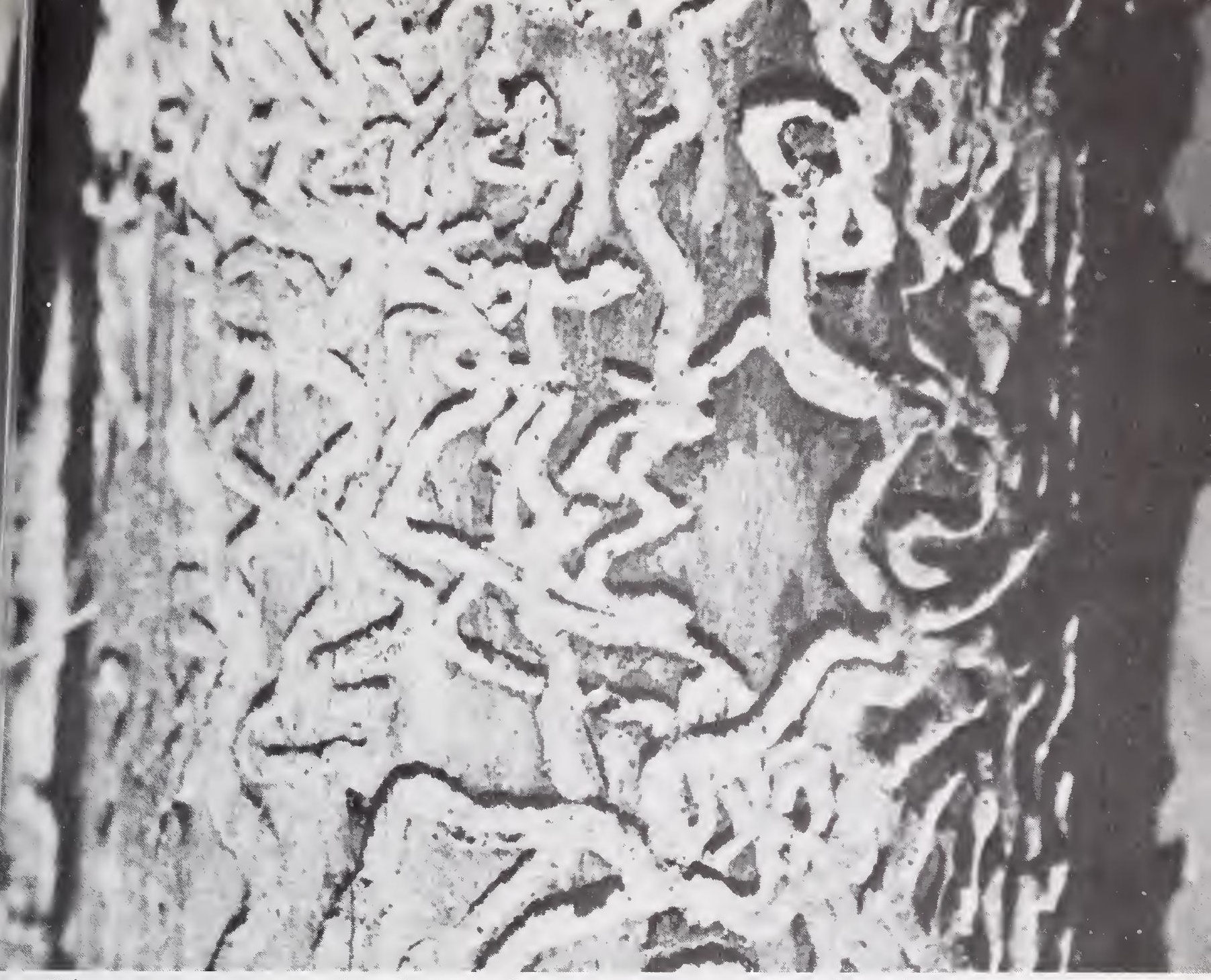

Figure 1.-Lamal mines of Agrilus politus (Say) on

scouler wizzow.

on tender bark or leaves. Some species feed on fungus spores and some frequent flowers where they feed on pollen.

LIFE CYCLE. The cycle takes 1 or 2 years, depending on the species. Larvae normally constitute the overwintering stage. Pupation usually occurs in the spring to early summer and lasts for approximately 2 weeks.

NATURAL CONTROL. Hymenopterous parasites appear to be an important regulating factor in populations of Agrizus spp. Parasitism accounting for losses of up to 50 percent of the population has been reported for some species.

\section{References}

Barr, William F. 1971. Family Buprestidae. P. 87-89, in: Hatch, Melville H. The beetles of the Pacific Northwest. Part V. Univ. Wash. Publ. Biol., Vol. 16.

Burke, H. E. 1917. Flatheaded borers affecting forest trees in the United States. U.S. Dep. Agric. Bul1. 437, 8 p. 
Fisher, W. S. 1928. A revision of the North American species of Buprestid beetles belonging to the genus Agritus. U.S. Nat. Mus. Bull. 145, 347 p.

\section{Anthaxia spp.}

RANGE. Throughout the Western United States and Canada.

HOSTS. Many plants, including species of Cercocarpus, Rosa, Amelanchier, Quercus, Prunus, Salix, Ceanothus, and Purshia tridentata (Pursh) DC.

DAMAGE. Branches and small twigs of host plants are frequently killed or damaged by the boring and girdling of the larvae. Host plants thus affected are unsightly and may attract other boring insects. The many species of Anthaxia are believed to be much more highly host specific than has been reported.

APPEARANCE AND HABITS. Eggs are not known. The larvae are smal1, cream-colored flatheaded borers. The first body segment is without distinct chitinous rugosities but has an inverted $\mathrm{V}$ on the dorsal surface and a median line on the ventral surface that does not reach the hind margin. The larvae are found beneath or in the bark of the host. Pupation is believed to take place in a specially constructed cell in the wood. The adults are small, conspicuously flattened and broadened; they are dark bronze, blackish, or green, and have characteristic pronotal reticulations. Adults are found on the foliage or flowers of the host plant, on flowers of various species of Compositae, or commonly on Eriogonum.

LIFE CYCLE. The cycle is not known, but is believed to last 1 year. Adults are found from early spring to midsummer, depending on the species and locality.

\section{References}

Barr, William F. 1971. Family Buprestidae. P. 67-73, in: Hatch, Melville H. The beetles of the Pacific Northwest. Part V. Univ. Wash. Publ. Biol., Vol. 16.

Burke, H. E. 1917. Flatheaded borers affecting forest trees in the United States. U.S. Dep. Agric. Bu11. 437, 8 p. 


\section{Dicerca horni Crotch and D. pectorosa LeConte}

RANGE. Throughout their host ranges in the Western United States and British Columbia.

HOSTS. Several browse shrubs. D. homi infests species of Ceanothus, Cercocarpus, and Alnus, whereas D. pectorosa infests species of Prunus.

DAMAGE. Larvae bore in dead wood of living trees and shrubs or in the wood of dead or dying trees and shrubs. They probably do not kill the plant by themselves.

APPEARANCE AND HABITS. The egg stage is not known. Larvae are typical large flatheaded borers. The first body segment lacks distinct chitinous rugosities but has an inverted $\mathrm{V}$ on the dorsal surface that is reticulated anteriorly and has a median line on the ventral surface that reaches the hind margin. Pupation is believed to occur in old larval galleries within the woody portions of the host plant. Adults are dark brown to coppery, 12 to $30 \mathrm{~mm}$ long, with a pair of longitudinal median ridges on the pronotum. $D$. homi usually has long fine hairs on the elytra. The front margin of the prosternum of $D$. pectorosa is broadly lobed laterally. The adults are found most often on the bark or foliage of the host plants. Their feeding habits are not known.

LIFE CYCLE. The details of the life cycle of these insects have not been recorded.

\section{Reference}

Barr, William F. 1971. Family Buprestidae. P. 67-73, in: Hatch, Melville H. The beetles of the Pacific Northwest. Part V. Univ. Wash. Pub1. Biol., Vol. 16.

\section{Cerambycidae: Roundheaded Wood Borers or Longhorned Beetles}

\section{Crossidius spp: Desert shrub longhorned rootborers}

RANGE. Arid and semiarid areas of the western States and Canadian Provinces.

HOSTS. Principally Chrysothomnus nauseosus (Pall.) Britt., C. viscidifloms (Hook.) Nutt., and Artemisia tridentata Nutt. 
REPRESENTATIVE SPECIES. C. hirtipes LeConte, $C$. punctatus LeConte, C. coralinus (LeConte), and C. ater LeConte.

DAMAGE. The larvae bore in the roots of the host plants. When $\overline{\text { larvae }}$ are numerous or when successive generations infest individual plants, partial killing or general unthrifty condition may result.

APPEARANCE AND HABITS. Eggs are deposited singly on the bark of stems and branches just above the soil surface. The eggs are covered with a protective secretion and coated with soil particles which give the egg a scalelike appearance. The larva is a typical roundheaded borer, white to creamcolored, legless, and up to $2-1 / 2$ inches long. The boring activities of this developmental stage may riddle the root. As many as 10 to 12 larvae may occupy a single plant. The pupa is large and yellowish and found generally in the wood just below the bark surface in the crown or down to 6 inches beneath the soil surface. Pupation occurs in the old larval boring tunnel. Adults are cylindrical with long antennae; they have characteristic colors and markings consisting of a yellow-brown or red base color and usually with a broad black apical band or an irregular sutural stripe on the elytra. The adults appear only during the late morning and early afternoon. They are found most commonly on the flowers of their host or related plants where they feed on pollen.

LIFE CYCLE. The cycle takes 2 years. Overwintering stages are the egg and medium-sized larva. Pupation generally occurs in late summer and lasts approximately 2 weeks. The adults are most evident during the early fall.

NATURAL CONTROL. The clerid beetles, Enoclerus acerbus (Wolcott) and $E$. abmutus (LeConte) have been reported as predators of the larvae.

\section{References}

Linsley, E. G., and J. A. Chemsak. 1961. A distributional and taxonomic study of the genus Crossidius (Coleoptera: Cerambycidae). Entomol. Soc. Am. Misc. Publ. 3:25-64.

Penrose, R. L. 1967. Bionomics of the species of Idaho Crossidius with taxonomy of immature stages. M.S. Thesis, Univ. Idaho, $69 \mathrm{p}$. 
Penrose, Richard L. 1973. A biosystematic study of the genus Crossidius north of Mexico (Coleoptera: Cerambycidae). $\mathrm{Ph} . \mathrm{D}$. Thesis, Univ. Idaho, $397 \mathrm{p}$.

\section{Desmocerus spp.: Elderberry longhorned borers}

RANGE. All the western States and British Columbia.

HOSTS. Several species of Scmbucus.

DAMAGE. Boring by the larvae may result in the weakening or killing of individual plant stems. Extensive plant mortality has not been reported.

APPEARANCE AND HABITS. The eggs are not known, but they are believed to be laid in crevices of the bark at the base of the plant. The larvae are typical roundheaded borers up to 3 inches long. They feed in the living roots and basal stems and may cause the formation of large galls up to 10 inches in diameter at the base of the stems. Before pupation, a larva will tunnel up into the base of a stem, construct a pupal chamber in the pith, and cut an exit hole to the bark which is then filled with frass. The cream-colored pupa has typically long antennae. Adults are large, attractively colored beetles; the elytra vary from uniform orange or red to greenish or blue-black with the lateral margins narrowly to broadly reddish. Sexual dimorphism occurs in several species. Specimens are most commonly encountered as they rest on the leaves of their host plant. Occasionally they can be found on flowers.

LIFE CYCLE. At least 2 years are required to complete a generation. Adults are active for a short time during the summer. Larvae of several different instars may overwinter. Pupation takes place as early as March and as late as June, depending upon the locality.

\section{References}

Craighead, F. C. 1923. North American Cerambycid larvae. Can. Dep. Agric. (N.S.) 27:86-88.

Webb, J. L. 1905. Description of a new species of Desmocemus with a synoptic table of the genus. Entomol. Soc. Wash. Proc. 7:104-105. 


\section{Chrysomelidae: Leaf Beetles}

\section{Altica spp: Leaf flea beetles}

RANGE. Throughout the western States and Canadian Province

REPRESENTATIVE SPECIES AND HOSTS. A. bimarginata Say, which infests Salix, and $A$. combiens (LeConte), which infests Alnus.

DAMAGE. Defoliation by adults and larvae can be severe locally. Reports of plant damage are made regularly each year. Plant mortality is uncommon, however.

APPEARANCE AND HABITS. The eggs are elongate, approximately $1.5 \mathrm{~mm}$ long, and pale to deep orange. They are laid singly or in groups of 30 or more on the leaves, stems, and branches of host plants and occasionally on other plants nearby The larvae are elongate and brown to black, with the head and thorax frequently shiny and the ventral surfaces yellowish. Larvae skeletonize the leaves of host plants. The pupae are orange to brownish in color and occur in the soil beneath the host plant. Adults are blue to metallic steel blue and 5 to 7 $\mathrm{mm}$ long. They tend to jump when disturbed. They perforate leaves of the host plant when feeding.

LIFE CYCLE. One, two, and perhaps more than two generations a year are known to occur. The adults overwinter and oviposit in the late spring. Eggs hatch in 5 to 10 days. Depen ing on the species, larval development is short, varying from 9 to 21 days, or is extended, ranging from 25 to 53 days. Pupation lasts from 6 to 10 days.

NATURAL CONTROL. Very few parasites or predators have been associated with these flea beetles. In Idaho, the principal population regulators are the predaceous bug Sinea diadema (Fabr.) and a predaceous beetle Lebia sp.

\section{Reference}

Barstow, D. A., and A. R. Gittins, 1971. Life history studies of a willow leaf beetle Altica bimarginata Say in north Idaho (Coleoptera: Chrysomelidae). Univ. Idaho Agric. Exp. Stn. Res. Bu11. 80, 20 p. 


\section{Disonycha spp: Five-striped flea beetles}

RANGE. The more semiarid areas of western North America.

REPRESENTATIVE SPECIES AND HOSTS. A relatively large number of species is represented in the genus. D. Zatiovittata Hatch infests Salix, whereas D. Latifrons Schaeffer infests Chrysothomnus.

DAMAGE Considerable defoliation of the host plants may occur locally but extensive damage or mortality has not been reported.

APPEARANCE AND HABITS. The eggs are yellowish and occur in groups on the host plant or in soil adjacent to the host plant. The larva is black with a distinct greenish or bluish luster. When mature it is approximately one-half inch long. Larvae usually occur in groups feeding on leaves on the host plant. Adults are ivory colored with narrow to broad black stripes on the elytra and discal markings on the thorax. The legs are red or orange. They occur on the host plant occasionally, along with the mature larvae. Pupation occurs in the soil.

LIFE CYCLE. Several generations a year may occur, depending upon the locality. The adult overwinters and lays eggs in the spring. Eggs hatch in 7 to 10 days. The larval stage lasts for up to 8 weeks and the pupal stage 3 to 6 weeks.

\section{Reference}

Blake, D. H. 1933. Revision of the beetles of the genus Disonycha occurring in America north of Mexico. U.S. Nat. Mus. Proc. 82:1-66.

\section{Trirhabda spp.} Canada.

RANGE. Throughout the United States and portions of

\section{REPRESENTATIVE SPECIES AND HOSTS: T. pilosa Blake,} which infests Artemisia tridentata Nutt., and T. nitidicollis LeConte and T. Zewisii Crotch, which feed on Chrysothomnus nauseosus (Pall.) Britt. and C. viscidiflorus (Hook.) Nutt. 
DAMAGE. Under local conditions, host plants may be severely defoliated. Outbreaks or localized plant mortality have been reported for C. nauseosus in New Mexico in 1957, and for A. tridentata in southeastern British Columbia in 1954 and 1961 and in southem Idaho in 1968.

APPEARANCE AND HABITS. The yellowish eggs are deposited singly or in clumps on the host or on litter around the base of the host. Larvae attain one-half inch in length. They are metaliic blue or green, rather elongate, and relatively slow moving. They feed in groups on the upper portion of the host plant. Larvae of several different sizes may be present at a given time. The yellowish pupae occur in the soil to a depth of several inches around the base of the host. Usually they are found in sand or sandy loam soil. Adults vary in color from dull yellowish with greenish to black pronotal spots and elytral stripes to green or blue-green, with or without pale stripes on the elytra. They are usually found feeding on the upper portion of the host plant.

LIFE CYCLE. There is one generation per year. In species thus far investigated, the egg is the overwintering stage. The larvae occur from early spring to midsummer depending upon the locality. Pupation lasts up to 2 weeks. Adults begin emergence in the spring and are active for several months.

NATURAL CONTROL. The tachinid fly, Aplomyiopsis xylota (Curran) has caused 18 to 40 percent mortality in larvae of Trirhabda lewisii, T. exiodictyonis, T. nitidicollis, T. pitosa, and T. manisi. The most common predator is the pentatomid, Perilzus splendidus (UhIer); the carabids, Philophuga viridis comoena LeConte and Lebia cyanipennis Dejean also prey on some species.

\section{References}

Blake, D. H. 1931. Revision of the beetles of the genus Trirhabda north of Mexico. U.S. Nat. News Proc. 79:1-36.

Hogue, S. M. 1970. Biosystematics of the genus Trirhabda LeConte of America north of Mexico (Chrysomelidae: Coleoptera). Ph.D. Thesis, Univ. Idaho, $212 \mathrm{p}$.

Hogue, Steve M. 1971. Trirhabda LeC. P. 193-196, in: Hatch, Melville H. The beetles of the Pacific Northwest. Part V. Univ. Wash. Publ. Biol, Vol. 16. 
Massey, C. L., and A. A. Pierce. 1960. Trirhabda nitidicolIis a pest of rabbitbrush in New Mexico. J. Range Manage. 13:216-217.

Pringle, W. L. 1960. The effect of a leaf feeding beetle on big sagebrush in British Columbia. J. Range Manage. 13:139-142.

\section{Curculionidae: Snout Beetles or Weevils}

\section{Rhynchites bicolor (Fabricius): Rose curculio}

RANGE. All the western States and Provinces of the United States and Canada.

HOST. Wild and cultivated Rosa.

DAMAGE. Niches are chewed in developing flower buds by adults while feeding and for ovipositing. Resulting flowers do not develop normally. Following oviposition, the female may puncture the flower stem, causing the bud to wilt and mummify .

APPEARANCE AND HABITS. Eggs are white, elliptical, about 1.2 by $1.1 \mathrm{~mm}$, and are found in the developing flower buds. Each female lays approximately 40 eggs. The larvae are white, curved, legless, and about $7 \mathrm{~mm}$ long. They develop in mummified buds that have remained on the plant or dropped to the ground. Pupation takes place in an earthen cell in the soil. Pupae are white. Adults are robust, somewhat pear-shaped, with a prominent beak. The upper surface of adults is bright red and the ventral surface and appendages are usually black.

LIFE CYCLE. There is one generation per year. Mature larvae overwinter in the soil. Pupation occurs from mid-March to early May and lasts for about 9 days, but the adults do not emerge from the soil until 2 weeks later. Adults are active throughout much of the summer. Eggs hatch in 1 to 2 weeks and larval development is complete in 6 to 12 weeks.

NATURAL CONTROL. An ichneumonid wasp Pemelucha sp. has been reported to parasitize larvae.

\section{References}

Balduff, W. V. 1959. Obligatory and facultative insects in rose hips, their recognition and bionomics.

P. 78-123, in: I11. Biol. Monogr. 26. 
Hoerner, J. L. 1936. Western rose curculio. Colo. Exp. Stn. Bul1. 432, 19 p.

\section{Sternochetus lapathi (Linnaeus): Poplar-and-willow borer}

RANGE. Native to Europe and Asia. It was.discovered in New York in 1882 and now occurs throughout southern Canada and the northern half of the United States.

HOSTS. Preferably Salix; much less commonly, Populus (but not Populus tremuZoides Michx.); and rarely, Alnus and Betula.

DAMAGE. Stems are killed either by mining or by breakage of the weakened part. Infestations occur more commonly near the ground and in stems 1 to 3 inches in diameter. Presence of infestation is indicated by wood fragments expelled by larvae through holes bored in the stem. Infestations are very common and usually persist in the same stem or plant for several years.

APPEARANCE AND HABITS. The egg is white and measures 1.1 by $0.8 \mathrm{~mm}$. Eggs are laid singly or in groups of two to four in holes chewed in the bark by the female beetle. The mature larva (fig. $2 \mathrm{~A}$ ) is about $1 \mathrm{~cm}$ long, white, legless, and $\mathrm{C}$-shaped, with a shiny reddish-brown head. Young larvae overwinter between the bark and the wood. In spring, they mine partly around the stem, then upward in the wood or pith for a distance of approximately $5 \mathrm{~cm}$. Before pupating, the larva orients itself headfirst toward the mine entrance. The adult (fig. 2B) is 7 to $10 \mathrm{~mm}$ long, dark brown to black, mottled with light brown and gray scales. The tips of the elytra, sides of the thorax, and parts of the legs usually have a pinkish cast. The body surface is dull and rather rough in appearance. Adults are said to be active during evening and morning but become inactive in daytime when temperatures exceed $26^{\circ} \mathrm{C}$. They do not take to flight readily and if disturbed, will feign death by dropping to the ground and remaining motionless with legs and beak closely drawn against the body. When held, both sexes emit an audible squeaking sound by rubbing the abdomen against the inner surface of the wing covers.

LIFE CYCLE. Accounts of the weevil's life cycle differ, apparently because of climate. In coastal British Columbia, adults emerge during summer and early fall. Eggs are laid during two peak periods: March and April by adults that overwintered and July through September by newly emerged adults. Pupation occurs from mid-July through September after the larvae have overwintered. 


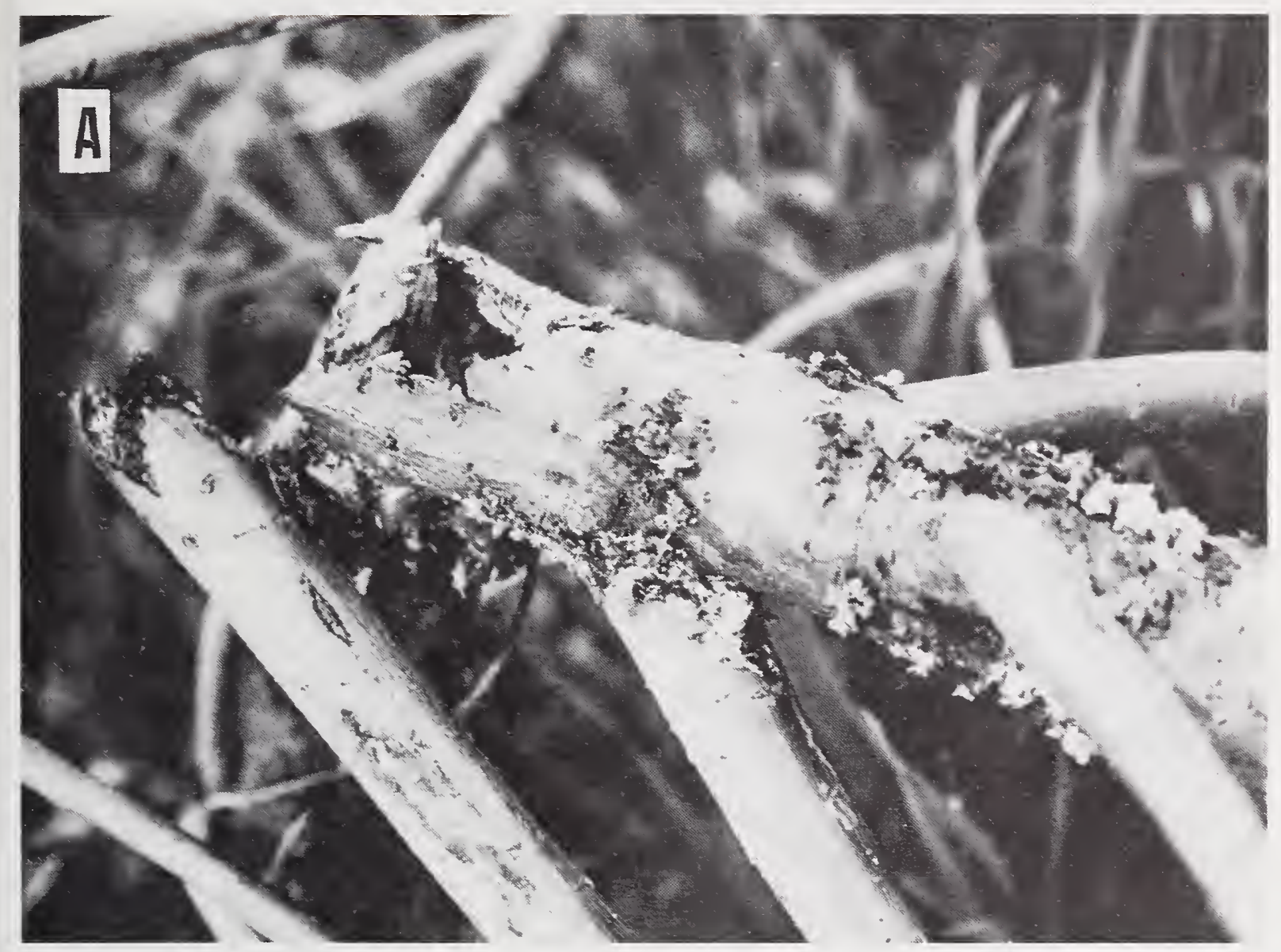

Figure 2.--A. Mining of wizlow stems by larvae of the poplar-and-willow borer subjects them to windbreakage. B. Adult weevil on bark where eggs are laid.

B

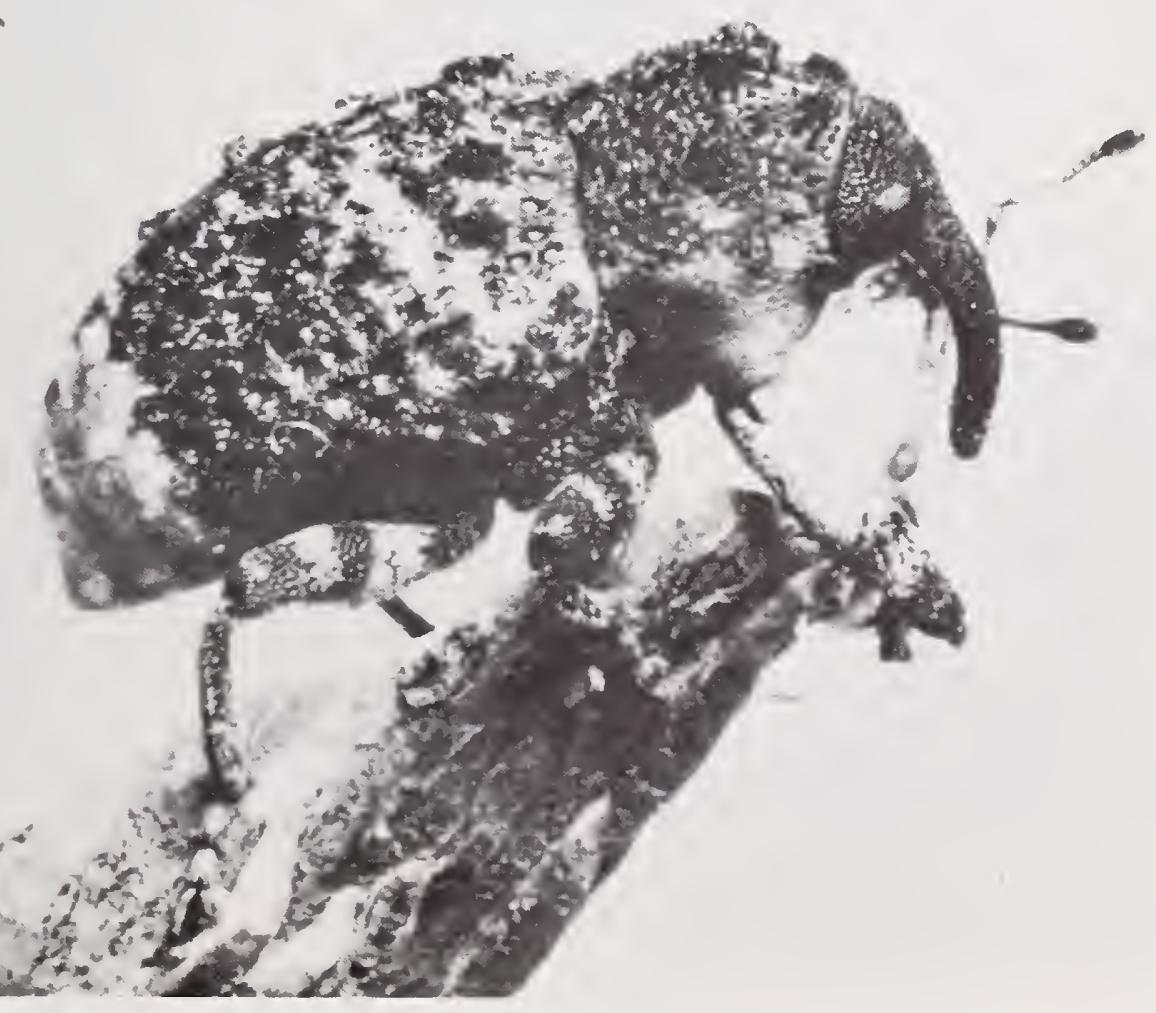


NATURAL CONTROL. The larvae are parasitized by an ichneumon wasp, Dolichomitus messor sparsus Townes.

\section{References}

Furniss, Ma1colm M. 1972. Pop1ar-and-willow borer. USDA For. Serv., For. Pest Leaf1. 121, 5 p.

Harris, J. W. E., and H. C. Coppe1. 1967. The poplar-andwillow borer, Stemochetus (= Cryptorhynchus) Zapathi (Coleoptera: Curculionidae), in British Columbia. Can. Entomol. 99:411-418.

\section{Scolytidae: Bark Beetles}

\section{Chaetophloeus heterodoxus (Casey) (= Renocis): Mountain mahogany bark beetle}

RANGE: Native to California, Nevada, Utah, Oregon, Montana, Idaho, Washington, and British Columbia.

HOSTS: Cercocarpus commonly; reported on AmeZanchier and Pmu

DAMAGE. Attacking beetles bore into the bark of the trunk and branches where they excavate oval egg chambers having three to six fingerlike projections. The larvae deeply etch the wood during their mining (fig. 3). Usually, the infested trees have been injured previously by other agents such as sapsucking birds; however, during 1951-52 the beetle killed extensive stands of mountain mahogany in Oregon without evident help. Infestations may persist in the same plant for several years.

APPEARANCE AND HABITS. The beet le is monogamous. From 6 to 12 eggs are laid in each projection of the adult chamber. The larvae are grublike, without legs. Their mines radiate from the egg chamber for three-fourths inch, tending not to overlap and increasing in width toward their ends where pupal cells are constructed. The pupal cells are mostly in the wood, an adaptation which apparently permits the beetle to inhabit thin-barked stems. The grayish-black adults are sma11, very stout beetles about 1.2-2.5 mm long. A sharp toothlike projection is present on the middle of the frons. The elytra are prominently striated lengthwise and basally ridged. Adult progeny exit through the bark, leaving circular holes three-fourths $\mathrm{mm}$ in diameter. 


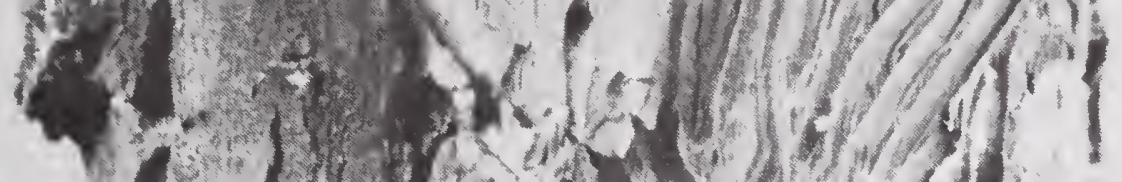

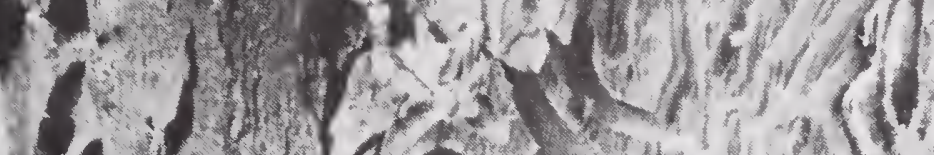

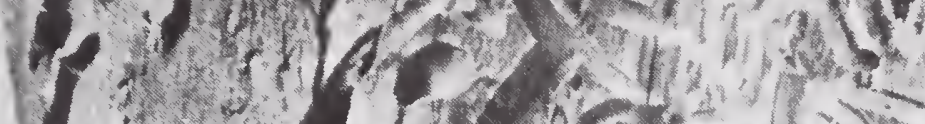

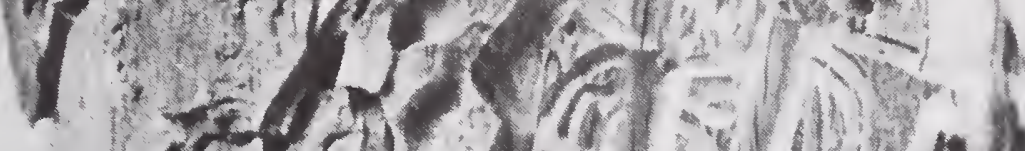

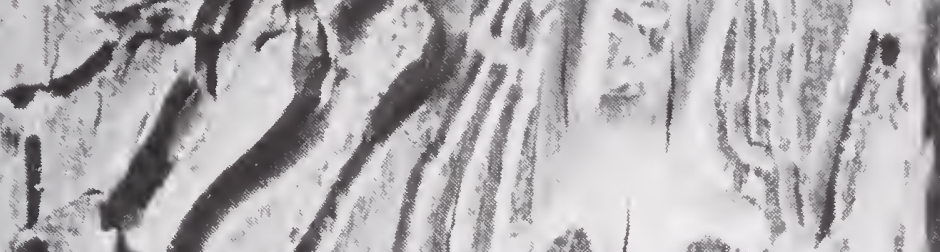

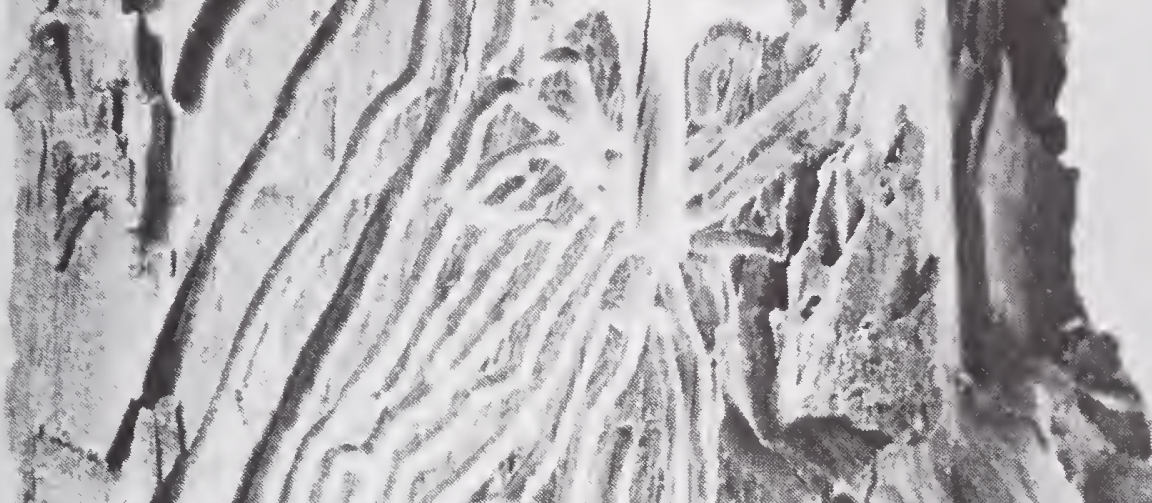

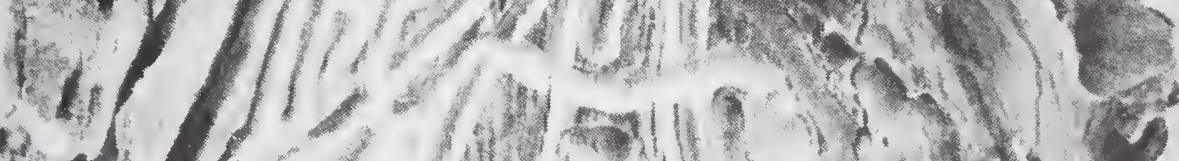

a.

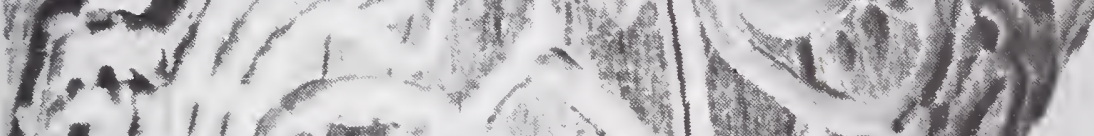

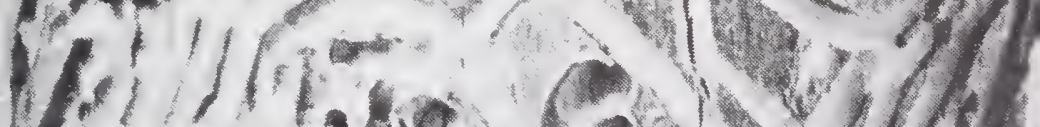

(1)

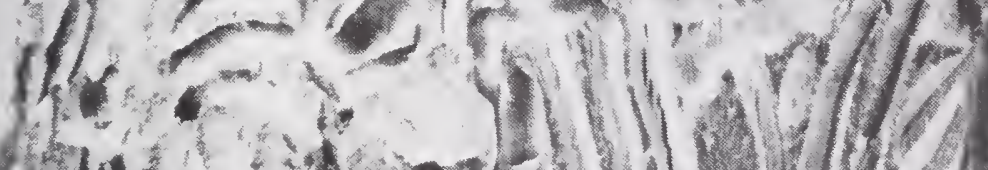

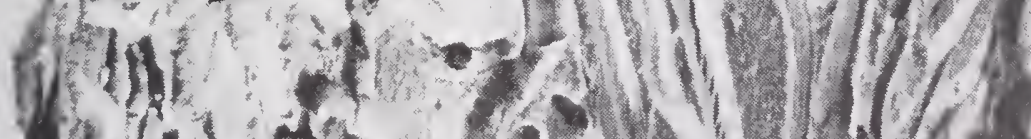

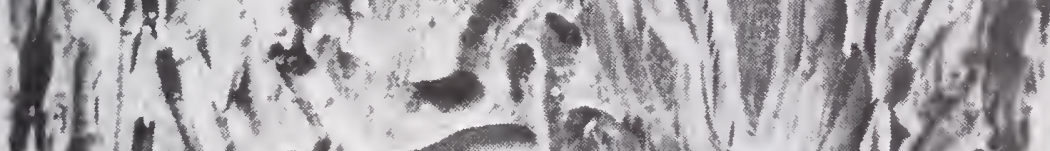

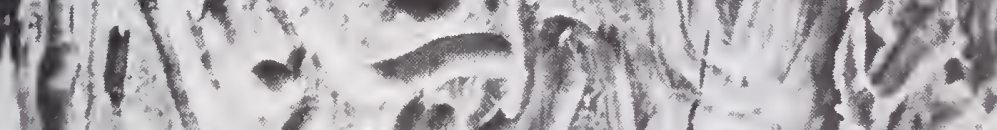

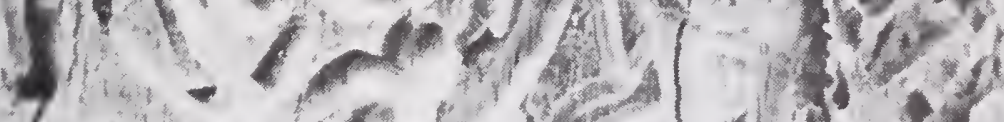

7.

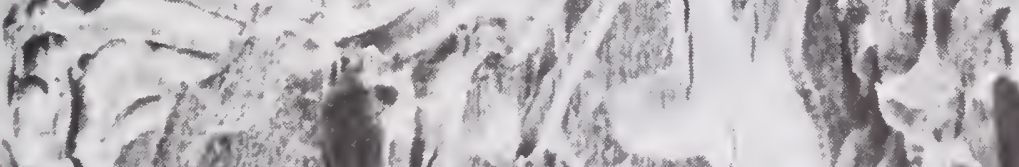

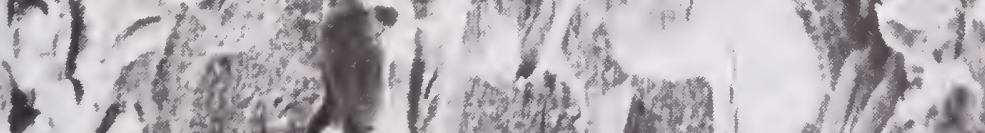

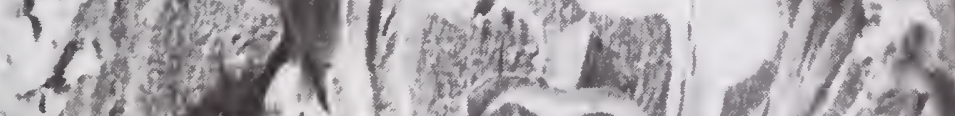

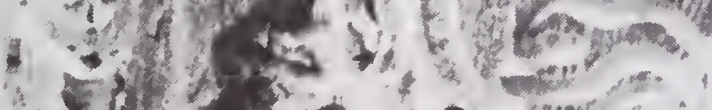

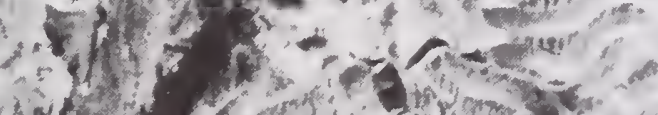

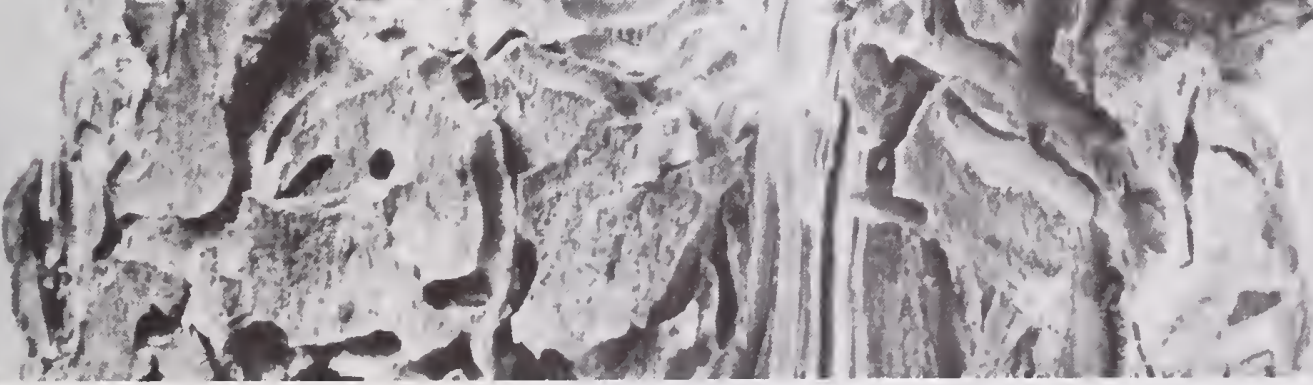

Figure 3.--This pattem was etched in the sapwood of mountain mahogany by the adults and larvae of the bark beetle, Chaetophloeus heterodoxus (Casey). 
LIFE CYCLE. Adults apparently overwinter in their galleries and eggs are deposited in March. Larvae transform to pupae by May 15 and adults are present by June 1. Flight and construction of new egg chambers begin in late July. A second generation may occur but this has not been demonstrated

NATURAL CONTROL. The following wasps have been reared from infested stems and may be parasites of the mountain mahogany bark beetle: Cephalonomia sp. (Bethylidae), Esphylus hypothenemi Ashm. (Braconidae), Eurytoma phloeotribi Ashm. (Eurytomidae), Erythromalus sp. (Pteromalidae), and Karpinskiella sp. (Pteromalidae).

\title{
References
}

Bright, D. E., Jr., and R. W. Stark. 1973. The bark and ambrosia beetles of California. Coleoptera: Scolytidae and Platypodidae. Univ. Calif. Press, Bull. Calif. Insect Surv. 16:1-169.

Chamberlin, W. J. 1955. Description of a new species of Phlceosinus and remarks regarding the life history and habits of Renocis heterodoxus. Pan-Pac. Entomol. $31: 116-120$.

Chamberlin, W. J. 1958. The Scolytoidea of the Northwest; Oregon, Washington, Idaho and British Columbia.

Corvallis, Oreg.: Oreg. State Monogr., Studies in Entomol. $2,208 \mathrm{p}$.

\section{DIPTERA: FLIES}

\section{Cecidomyiidae: Gall Midges}

\section{Mayetiola sp. (= Phytophaga): Bitterbrush seed midge}

\author{
RANGE AND HOST. Purshia tridentata (Pursh) DC., in \\ Idaho and Oregon.
}

DAMAGE. Larvae enter the base of the seed husk and complete their development between the husk and the seed. Infested seeds (fig. 4A) fail to develop normally in width and are retained on the plant overwinter, whereas healthy seed are plump and drop in early summer. In 1962, this midge destroyed 6.8 percent of a sample of seed examined east of Boise, Jdaho. 


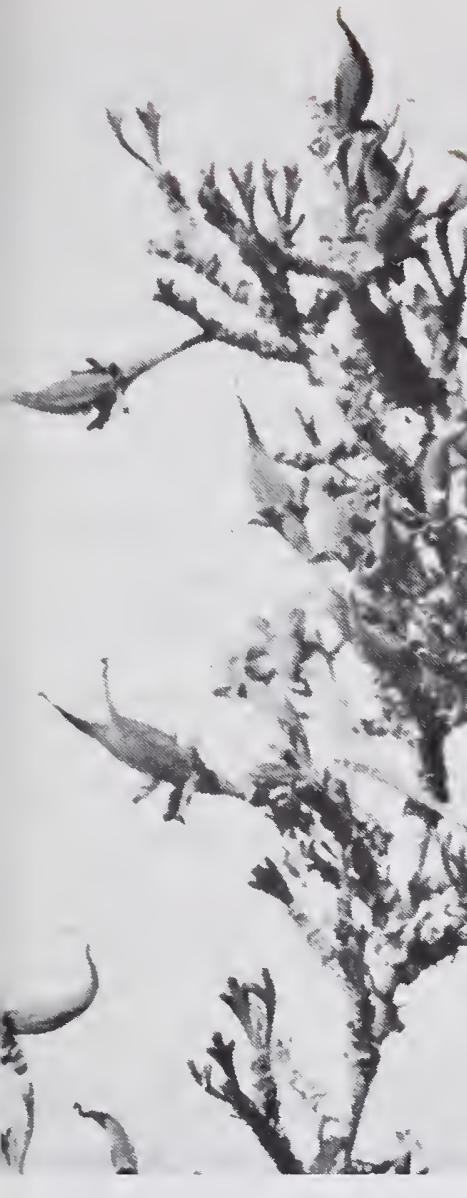

Figure 4.--Bitterbrush fruits infested with Mayetiola sp. wither and persist on the plant (A) after normal seed drop. The "Jlax seed" stage (B) occurs within the seed husk and contains the last instar Iarva.
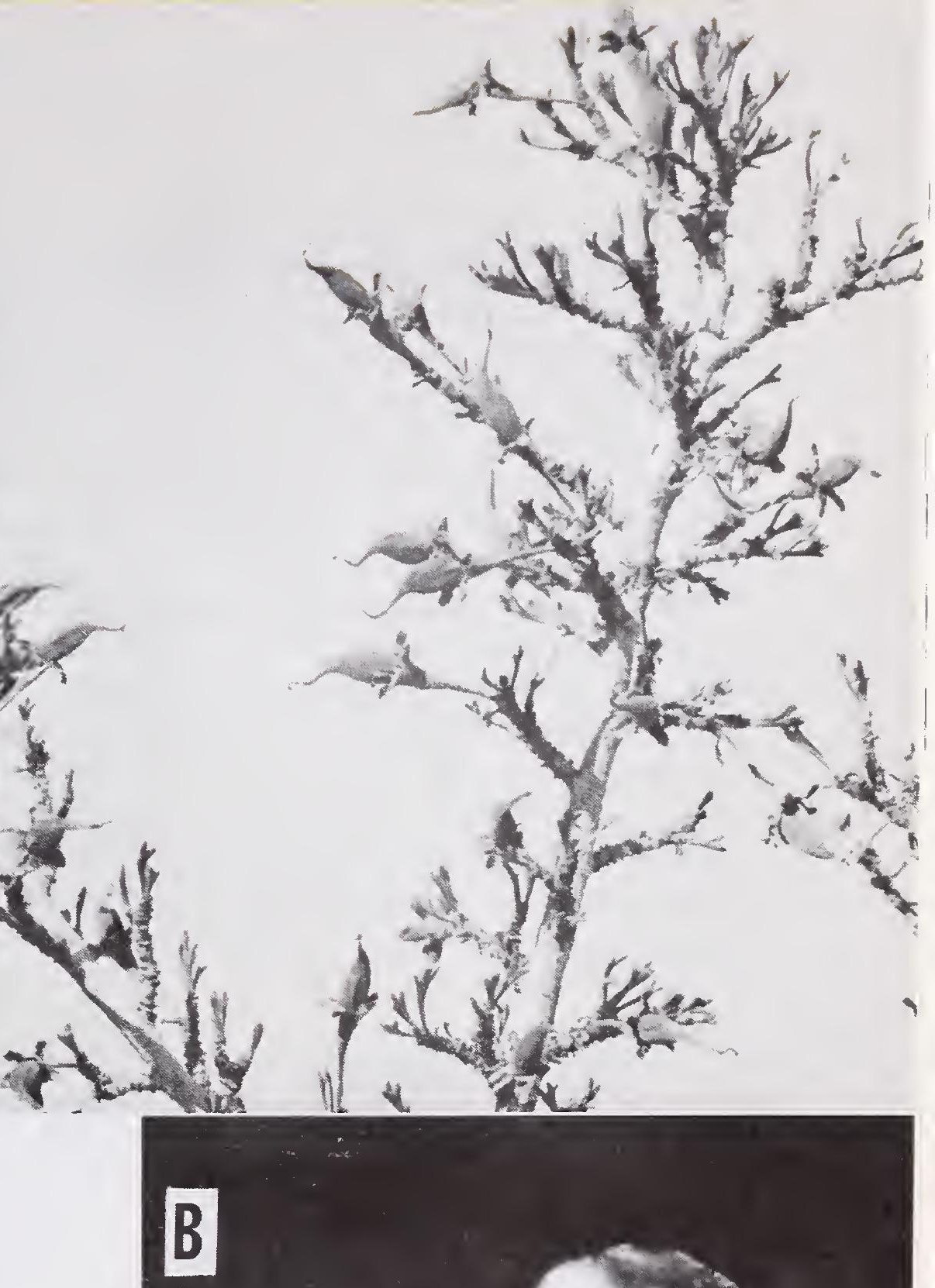
APPEARANCE AND HABITS. One to several eggs are laid between the seed husk and its calyx tube. The legless, orange larva attains a length of $2 \mathrm{~mm}$. It lacks a distinct head and its mouth parts are retracted, appearing only as a black spot. From one to several larvae may be present inside the husk of a single seed. They are usually accompanied by larvae of parasitic wasps, but these are paler in color. The shiny brown puparium (fig. 4B) is called the "flax seed" stage. The adult is difficult to rear and has not been positively associated with the immature stages. Adults of this genus are typically very small, delicately built flies with relatively long legs and antennae.

LIFE CYCLE. Eggs are laid in May. Naked larvae are present until the second week in June, after which they form puparia in which they pass the winter. Adults are believed to emerge in May and apparently survive for only a brief time.

NATURAL CONTROL. The eulophid wasps, Aprostocetus sp. and Tetrastichus sp. are common parasites of the larvae.

\section{Reference}

Ferguson, R. B., M. M. Furniss, and J. V. Basile. 1963. Insects destmuctive to bitterbmush flowers and seeds in southwestern Idaho. J. Econ. Entomol. 56:459-462.

\section{Tephritidae: Fruit Flies}

\section{Eutreta, Procecidochares, and Aciurina spp.: Gall forming fruit flies}

RANGE. Widely distributed in western North America.

HOSTS. Commonly browseland shrubs, including species of Artemisia and Chrysothoomus.

DAMAGE. These insects cause galls to be formed on the buds, flowerhead, leaf axils, leaves, and branches or twigs. When abundant, they give the plant an unsightly appearance; they may also cause reduced growth and, in some instances, plant mortality.

APPEARANCE AND HABITS. Eggs are laid singly in or on plant tissue. A secretion from the ovipositing female or 
feeding larva is believed to cause a reaction by the plant which produces a specific kind of gall in which larval development occurs. The larva is small and maggotlike. The pupa is usually chunky, and enclosed in a dark brown cylindrical case within the gall. The adult is variable in size and appearance. Usually it has variegated or pictured wings but some species may have wings almost entirely black. The galls vary greatly in size and appearance. They may be hard, somewhat pearlike expansions of the small branches: e.g., Eutreta diana (Osten Sacken) on Artemisia tridentata iNutt.; cottony white swellings or flowerlike swellings of the buds; green flowerlike outgrowths of leaf axils; or sticky globular swellings attached to a stem: e.g., Aciurina trixa Curran on Chmysothomnus nouseosus (Pal1.) (fig. 5). Many of the galls are similar to those formed by midges (Cecidomyiidae).

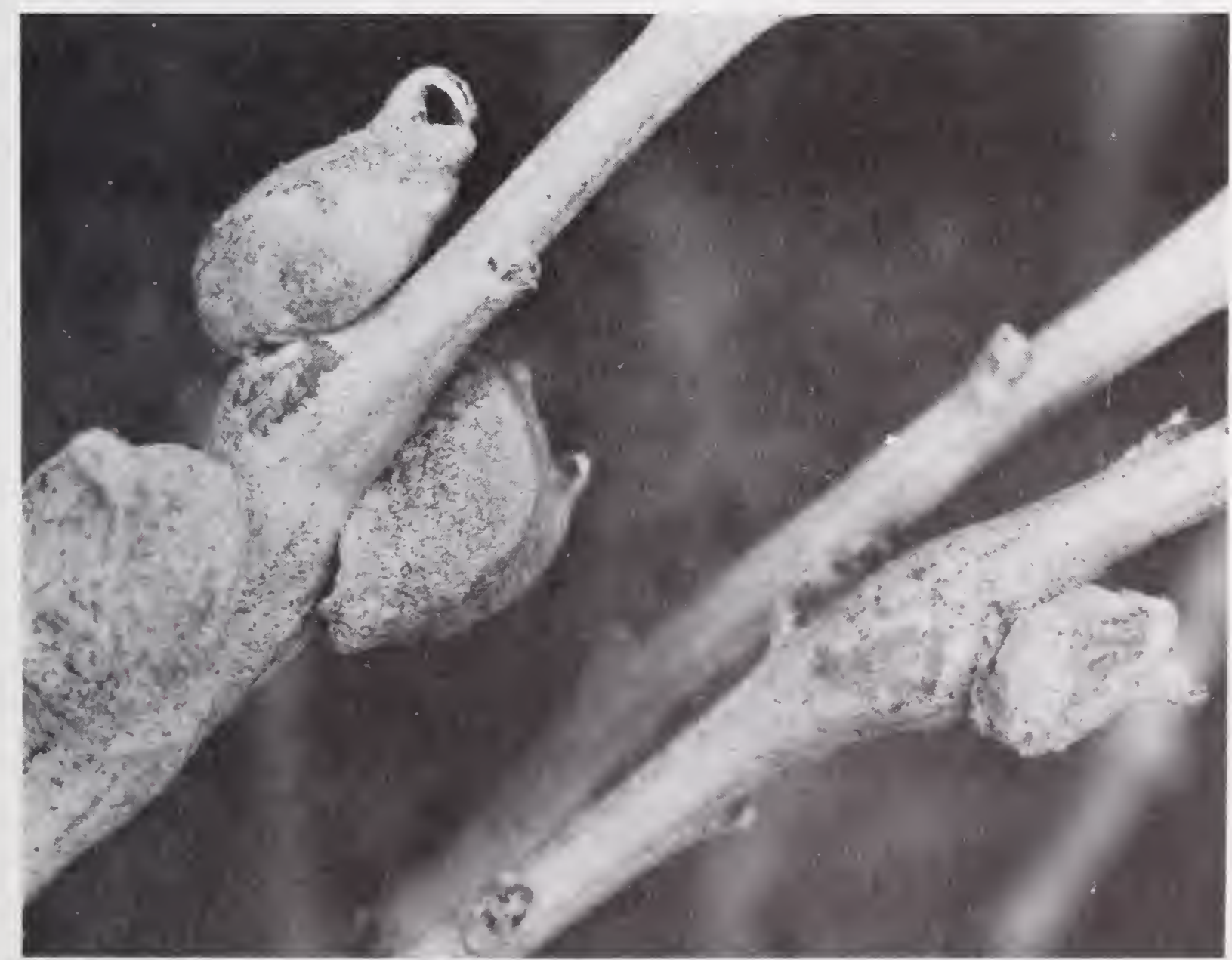

Figure 5.--Galls of the fruit fly, Aciurina trixa. Cuman, on a branch of mbber rabbitbmsh. 
LIFE CYCLE. The life cycle usually lasts 1 year, but two or more generations per year may occur. Adults are active for 1 to 4 weeks and occur at specific times of the year. Overwintering takes place as eggs or larvae. The pupal period lasts for 1 to 2 weeks.

NATURAL CONTROL. Many parasites of the larvae and pupae have been found. They appear to have considerable influence on population levels of the various species. In Idaho the following hymenopteran parasites have been reared from the galls of Eutreta diana: Torymus sp., Eurytoma sp., Halticoptera stella Girault, SpiZochalcis Zeptis Burks, Habrocytus sp., Eupelmus sp., and Tetrastichus sp. The following have been reared from galls of Aciurina spp.: Eupelmus sp., Tetrastichus sp., Torymus sp., Eumytoma sp., Halticoptera stezla Girault, Amblymerus sp., and Bracon sp.

\section{Reference}

Foote, Richard H., and F. L. Blanc. 1963. The fruit flies or Tephritidae of California. Univ. Calif. Press, Bul1. Calif. Insect Surv. 7:1-117.

\section{HEMIPTERA: TRUE BUGS}

\section{Pentatomidae: Stink Bugs}

\section{Chlorachroa sayi (Stäl): Say stink bug}

RANGE. All western States and Alberta, Canada.

HOSTS. Purshia tridentata (Pursh) DC., grain crops, grasses and weeds.

DAMAGE. C. sayi punctures and sucks juice from developing bitterbrush seeds during late spring. These seeds develop necrotic spots and have only half the germination capacity of unspotted seeds. The stink bug also drastically reduces the yield of wheat and other grains by killing the seed heads of infested plants.

APPEARANCE AND HABITS. The egg is irregularly ovoid in shape, $1.2 \mathrm{~mm}$ long, $0.9 \mathrm{~mm}$ wide at the top, and $0.6 \mathrm{~mm}$ wide at the bottom. The top is marked in a bull's-eye pattern by circles of white and gray. From 20 to 50 eggs are deposited, 
usually in a double row on stems, or in clusters if laid on larger surfaces such as a leaf. Incubation period averages 9 days. The top of the egg consists of a lid which is opened by the nymph with the aid of a chitinized shell burster. The nymphs pass through five instars varying in length from 1.1 to $10.6 \mathrm{~mm}$. They have rather prominent four-segmented antennae (that of the adult is fivesegmented). The first three instars are basically black with the shelflike lateral margins yellow, white, or redorange in each of the first three instars, respectively. Additional areas of yellow-white occur dorsally. The last two instars are basically pale green; the margins are white with an orange edge. Wing pads first become evident in the fourth instar. The average total nymphal period is 43 days. The adult (fig. 6) is normally deep green color but varies from a pale yellowish green to reddish brown. During hibernation, its color changes to greenish pink. The rather long beak is hidden beneath the body and extends backward to the base of the hind legs. New adults do not oviposit for a month or more; late-developing adults do not oviposit

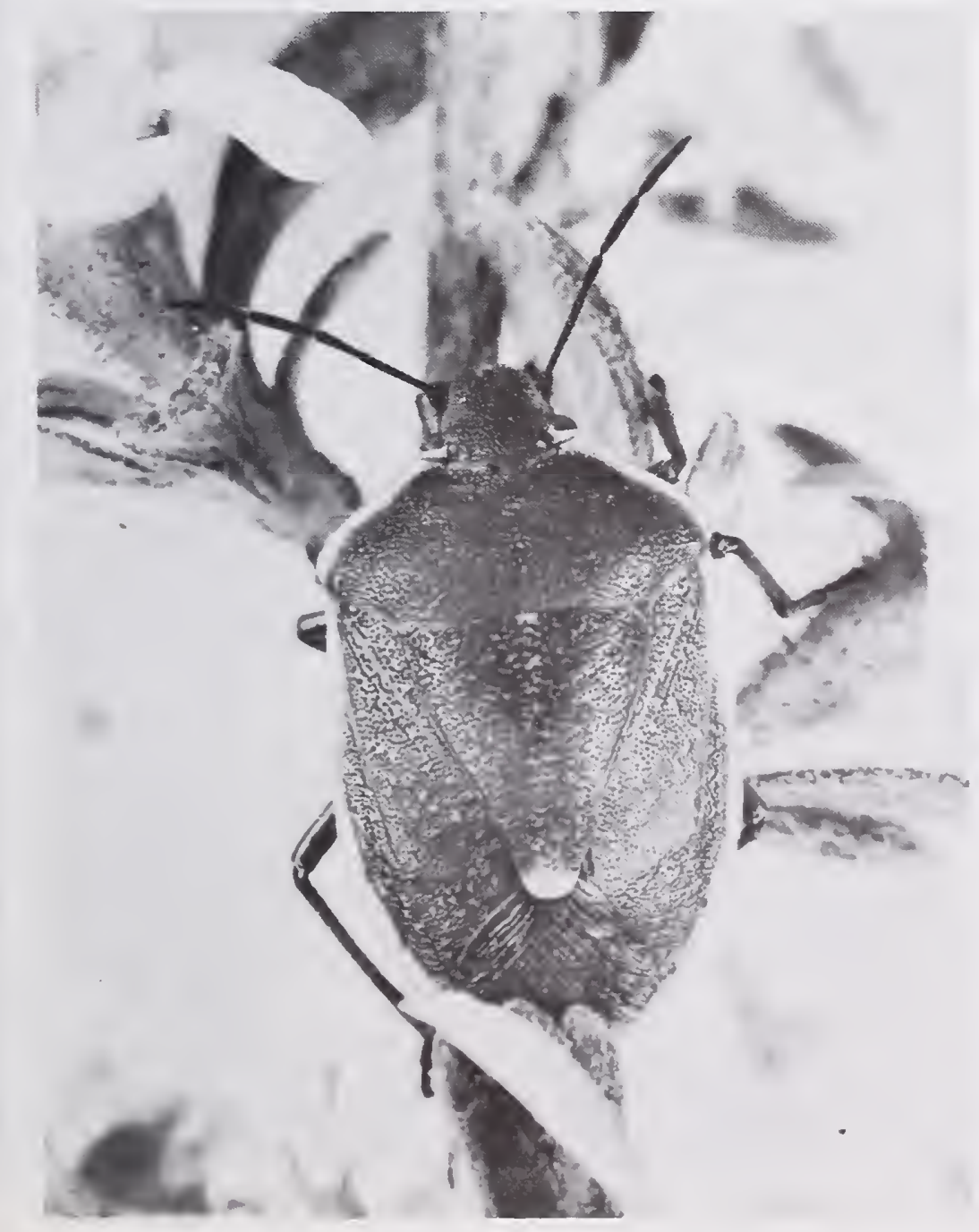

Figure 6.--An

Aduzt say stink bug on bitterbrush. Feeding by this bug Zowers the viability of seed. 
until the following spring. The adult is not easily flushed from its host and is a sluggish flier. If touched, it exudes a pungent-smelling liquid from two glandular openings near the attachment of the middle legs.

LIFE CYCLE. With the advent of cold weather in October or November, adults hibernate in protected places afforded by plant debris and rubbish. They emerge from hibernation during the first warm days of late April and early May. Eggs are laid soon thereafter. The resulting nymphs attain maturity about the last week in June. A second generation matures about the first week in August and establishes a third generation that matures about the middle of September. Most of the females of this last generation do not oviposit until the following spring.

NATURAL CONTROL. Winter kills any nymphs that have not matured before cold weather starts. Eggs are parasitized by the wasp, Telonomus ashmeadi Morril, and adults are parasitized by two tachinid flies, Gymnosoma fuliginosa Desv. and ocpterodes euchenor Walk. The first two named parasites accounted for 60 percent of the eggs and 25 percent of the adults in one study, whereas 0 . euchenor was uncommon.

\section{Reference}

Caffrey, D. J., and G. W. Barber. 1919. The grain bug. U.S. Dep. Agric. Bul1. 79, 35 p.

\section{HOMOPTERA: APHIDS, LEAFHOPPERS, PLANTHOPPERS, SCALE INSECTS, and ALLIES}

\section{Coccidae: Soft Scales}

\section{Lecanium cerasifex Fitch: Bitterbrush tortoise scale}

RANGE AND HOST. Occurs on Purshia tridentata (Pursh) DC. in Oregon, Idaho, and Montana.

DAMAGE. The female scale attaches herself to the host plant and feeds on sap by inserting her beak into a branch. Terminal branches that are heavily infested gradually die. The possibility that a plant disease is transmitted has not been studied. 


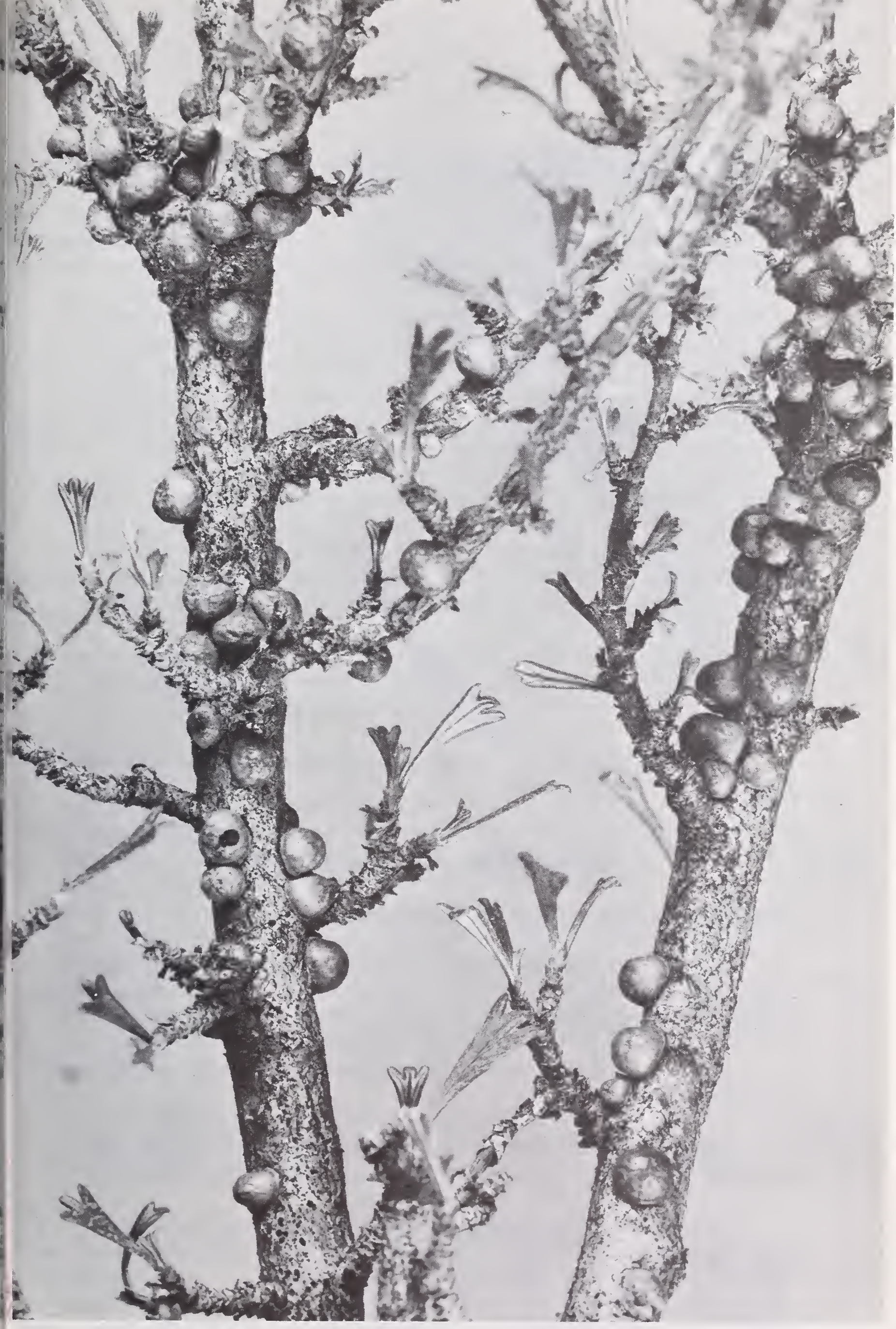

Figure 7.--The bitterbmush tortoise scale on bitterbmush stems. The females illustrated here are inmobile and Zaden with eggs. 
APPEARANCE AND HABITS. The scale has only recently been identified from bitterbmush and has not yet been studied in detail. The white, oval egg measures 0.3 by $0.2 \mathrm{~mm}$. More than 200 eggs are laid, hidden from view beneath the female while she is attached to a branch. The nymphs are mobile and are roughly $0.8 \mathrm{~mm}$ long. Their appendages are visible from above and the body is moderately elongated. The scales are probably disseminated in the nymphal stage by wind. The adult female (fig. 7) is nearly hemispherical, 33 to $40 \mathrm{~mm}$ long, and 25 to $33 \mathrm{~mm}$ wide. She is immobile, though possessing inconspicuous appendages, and remains closely attached to the branch for the duration of her life. Viewed dorsally, the posterior of the female has a small slit, possibly used as an exit by the newly hatched nymphs. During egg laying, the female integument is somewhat frosty in appearance but becomes shiny brown thereafter. Infested branches are moist with honeydew or sap in springtime. Ants and ladybird beetles search out and feed on this liquid.

LIFE CYCLE. The scale apparently has one generation per year. Eggs are laid in May. Time of hatching and attainment of other stages have not been studied.

NATURAL CONTROL. An unidentified small wasp commonly parasitizes the scales.

\section{Diaspididae: Armored Scales}

\section{Lepidosaphes ulmi (Linnaeus): Oystershell scale}

RANGE. A cosmopolitan insect; introduced into North America many years ago. It can be found in all the western States and Canadian provinces.

HOSTS. Salix, Amelanchier, Rosa, and many other kinds of shrubs and trees.

DAMAGE. Adults on limbs and branches suck the sap and may partially or completely kill the host plant.

APPEARANCE AND HABITS. The tiny cylindrical eggs are deposited and retained under the protective scale of the female. Twenty to 100 are usually present. Newly hatched nymphs or crawlers are pale in color, flattened, and have short legs and antennae. Characteristic structural parts are lacking. After wandering over the bark surface of the host, the nymph inserts its long slender mouth parts or stylets 
Figure 8.--Aduzt female oystershell scales on stem of willow.

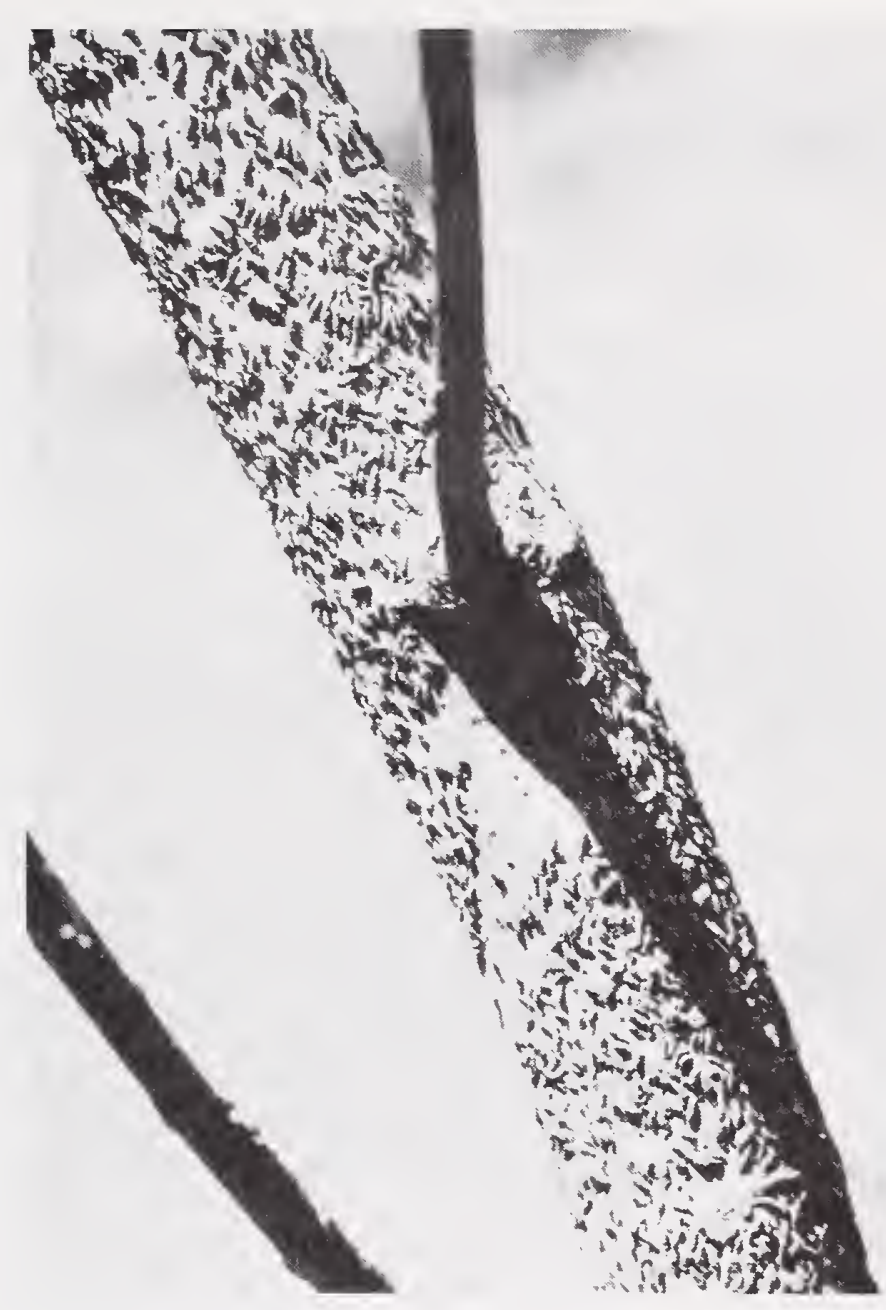

into plant tissue and then settles down for a sedentary life. A characteristic waxy secretion is deposited over the body. The adult male and female are considerably different in appearance. The female resembles the nymph but has a scaly covering that is gray to brown, slightly annulated, and shaped like an elongate oystershell (fig. 8). It is approximately one-eighth inch long. The male undergoes a metamorphosis and upon emergence resembles a tiny fragile fly with two wings but with aborted mouth parts and elongate antennae. Males are rare and parthenogenetic reproduction may be the rule for this species.

LIFE CYCLE. One to two generations per year occur in this area depending upon local conditions. The eggs are the overwintering stage.

\section{Reference}

Graham, S. A., and F. B. Knight. 1965. P. 283-285, in: Principles of Forest Entomology, 4th ed. 417 p. McGraw-Hi11, New York. 


\section{Ortheziidae: Ensign Scales}

\section{Orthezia artemisiae Cockerell: Sagebrush orthezia}

RANGE. Califomia, New Mexico, Nevada, Washington, and I daho.

HOSTS. Several species of sagebrush, Artemisia tridentata Nutt., A. tripartata Rydberg, and A. califomica and others.

DAMAGE. Branches are killed or weakened when large numbers of individuals are present. No extensive plant mortality is known.

APPEARANCE AND HABITS. The mature female is covered with $\overline{l o n g}$, fluted, white waxy secretions that also enclose the egg sac. Total length is approximately $10 \mathrm{~mm}$. Partially grown crawlers are covered with a white waxy secretion and have a characteristic fringe of wax around the body. The mature female is most often found on the upper branches of the host plant and is tended by ants which collect honeydew from her. In Idaho, two species of ants, Formica sp. and Dorymyrmex paramicus (Roger), have been associated with this orthezian .

LIFE CYCLE. Not known.

\section{Reference}

Morrison, Harold. 1952. Classification of the Ortheziidae.

U.S. Dep. Agric. Tech. Bul1. 1052, 80 p.

\section{HYMENOPTERA: ANTS, BEES, SAWFLIES, WASPS, and ALLIES}

\section{Formicidae: Ants}

Pogonomyrmex occidentalis (Cresson) and P. owyheei Cole: Western harvester ant and owyhee harvester ant

RANGE. Semiarid parts of the Northwest.

HOST. Sagebrush communities, where they defoliate numerous annual and perennial plant species, including A. tridentata. 
DAMAGE. These ants clear circular areas up to 30 feet in diameter of all annual vegetation and may then defoliate and kill shrubs in the clearing. Up to 8 to 10 percent of a rangeland site may be denuded by these ants. They also devour seeds.

APPEARANCE AND HABITS. An underground nest is located within the center of the cleared area. The nest may have several entrances, usually associated with a small mound of soil and pebbles. Within the nest all developmental stages of the ant can be found. The larvae are small, shiny white, and maggotlike in appearance. Pupae are enclosed in a tannish parchmentlike covering, through which they are not discernible. Adults are moderate size, uniformly reddish brown, and indistinctly clothed with fine, pale hairs. The sexual forms are winged.

\section{LIFE CYCLE. A colony is active throughout the year,} although much of the activity is beneath the soil surface and is greatly influenced by temperature and moisture. An annual brood of winged adults is produced which fly in late June or early July. The workers can inflict painful stings on man and livestock.

\section{References}

Crowe11, H. H. 1963. Control of the western harvester ant, Pogonomyrmex occidentalis, with poisoned baits. J. Econ. Entomol. 56(3):295-298.

Lavigne, Robert J., and Herbert G. Fisser. 1966. Controlling western harvester ants. Mt. States Reg. Publ. 3, 4 p.

Sharp, Lee A., and W. F. Barr. 1960. Preliminary investigations of harvester ants on southern Idaho rangelands.

J. Range Manage. 13(3):131-134.

\section{LEPIDOPTERA: MOTHS, BUTTERFLIES, SKIPPERS}

\section{Ethmiidae: Ethmiid Moths}

\section{Ethmia discostrigella (Chambers): Mountain mahogany leaf notcher}

RANGE. Califomia, Oregon, Idaho, Nevada, Utah, Colorado, Arizona, New Mexico, western Texas, northern Chihuahua, and Baja California. 
HOSTS. Cercocarpus Zedifolius Nutt., C. montanus Raf., and C. minutiflorus A. Gray.

DAMAGE. Feeding by the larvae creates irregular notches in the leaf edges but leaves are seldom completely consumed.

APPEARANCE AND HABITS. The egg is pink, 1.2 by $6 \mathrm{~mm}$, oval, flattened, and somewhat irregular in outline. Hatching occurs in about 10 days at room temperature. The mature larva may attain $19.5 \mathrm{~mm}$ in length and has either a dark orange or yellow dorsal band. Its head capsule is orange, and the remainder of the body is either mottled blackish or mottled pale gray. Pupation occurs within a dense, flat, white cocoon in litter, bark, hollow annual plants, etc. The pupa is brown, 8 to $9 \mathrm{~mm}$ long, flattened, and has characteristic "anal legs" anchoring it to the cocoon. The adult is attractively colored and marked. Its wingspan is 20 to $25 \mathrm{~mm}$. The forewings, head, and pronotum are gray with distinct black submarginal spots along the outer wing and a few elongated black spots along the center of the wing and on the sides of the pronotum. The tips of the forewings are silvery and one silver spot occurs toward the center. The hind wings and abdomen are a beautiful satiny gold. Adults are nocturnal and are attracted to light. Oviposition occurs at dusk and after dark on fibrous surfaces.

LIFE CYCLE. Moths fly during June at which time eggs are 1aid. Larvae are present from July through mid-September. winter is passed in the pupal stage.

NATURAL CONTROL. Natural control factors are unknown except for two ichneumon wasps, Meteoms sp. and TemeZucha sp., reared from parasitized larvae.

\section{Reference}

Powe11, J. A. 1971. Biological studies on moths of the genus Ethmia in California. J. Lepid. Soc. 25 (Suppl. 3):46-50.

\section{Gelechiidae: Gelechiid Moths}

\section{Aroga websteri Clarke: Sagebrush defoliator}

RANGE. Northern California, eastern Oregon and Washington, southem Idaho, Nevada, Utah, and portions of western Montana. 
HOSTS. Artemisia tridentata Nutt., A. Zongizoba Osterhout, A. tripartata Rydberg, A. nova Nelson $A$. arbuscula Nutt., A. rigida (Nutt.) Gray, A. cana Pursh, and others.

DAMAGE. Big sagebrush is most seriously affected under low or moderate population densities of the moth. Individual plants are partially or entirely killed through defoliation. Under high population densities, entire stands involving thousands of acres of the host plant may be eliminated.

\section{APPEARANCE AND HABITS. The eggs are globular, white} to ye llowish, and approximately one-half $\mathrm{mm}$ in diameter. They are deposited singly or in small groups on the bark of terminal stems of the host plant, but are rarely seen. The larva is creamy white to greenish with a dark head and prothoracic shield and small dark spots on the sides of the body segments. Mature larvae are approximately $12 \mathrm{~mm}$ long. Newly hatched larvae mine the leaves of the host; as they mature they enclose leaves and terminal branches in a mass of webbing in which they live and feed. When disturbed, a larva drops from its webbing and hangs by a silken thread. The pupa is smooth, brown, strongly pointed at its apex, and 7 to $10 \mathrm{~mm}$ long. Pupation takes place in the larval webbing. Adults are small gray moths with a wingspan of about $15 \mathrm{~mm}$. The front wings are gray with or without small conspicuous black markings. The hind wings are paler and have a fringe of long gray hairs along the hind margin. The adults are secretive and primarily nocturnal, but will fly when disturbed during the day. They are attracted to lights.

LIFE CYCLE. There is one generation per year. Eggs or tiny larvae overwinter and resume their development during the spring and early summer. Pupation, which lasts from 3 to 4 weeks, takes place in late June and early July. Adults live for 2 to 3 weeks.

NATURAL CONTROL. Twenty species of hymenopterous parasites have been associated with the sagebmush defoliator in Idaho. of these, an encyrtid, Copidosoma bakeri (Howard); an ichneumonid, Phaeogenes arogae Gittins and Henry; and a chalcidid, Spizochalcis Zeptis Burks, are the most abundant. They attack the larva. The moth and the larva are preyed on by two beetles, a clerid, Phyzzobaenus subfasciatus (LeConte), and a carabid, Phizophuga amoena LeConte. 
Fillmore, 0. 0. 1965. The parasitoids of Aroga websteri Clarke (Lepidoptera: Gelechiidae) in southern Idaho. M.S. Thesis, Univ. Idaho, 129 p.

Hal1, Ralph C. 1965. Sagebrush defoliator outbreak in northern California. U.S. For. Serv. Res. Note PSW-75, 12 p.

Henry, J. H. 1961. The biology of the sagebrush defoliator Aroga websteri Clarke in Idaho (Lepidoptera: Gelechiidae) M.S. Thesis, Univ. Idaho, $58 \mathrm{p}$.

\section{Filatima sperryi Clarke: Dark bitterbrush leaf tier}

\section{RANGE AND HOST. Idaho and Montana on Purshia tridentata (Pursh) DC.}

DAMAGE. Damage is similar to that caused by Gelechia mande $\overline{Z a}$ Busck. and both may occur on the same plants. Young larvae destroy seed by mining through the husk and feeding within the seed. In a local area of southwestern Idaho, 5.2 percent of the seeds were lost in this manner during 1961. After emerging from the seed, larvae cause additional damage by feeding on foliage of the shrubs.

APPEARANCE AND HABITS. The egg has not been observed. The mature larva is $14 \mathrm{~mm}$ long and has a shiny black head capsule, prothoracic shield, and anal plate. The body has six dark brownish stripes running lengthwise. The young larva mines into a seed husk at its middle and plugs the entrance hole with silk which protrudes outward (fig. 9). When through feeding, the larva exits through a clear opening, often near the apex of the husk. Thereafter, the larva constructs a silken tube, open at both ends, which may web together several leaves. If disturbed, a larva emerges backward from its tube by rapid, erratic movements. The pupa is formed within a white silken cocoon in webbing on the plant. The adult moth has a wingspan of 15 to $19 \mathrm{~mm}$. Moths appear to be rather uniform dark brown, but under magnification the forewings are somewhat mottled orange and brown on their upper surface. The forewings are darker than the hindwings and the trailing edge of the latter is adorned with a fringe of feathery scales which are nearly as long as the width of the hindwing. Maxillary palps form hornlike processes that curve forward and upward from beneath the head. The moths are active at night. 

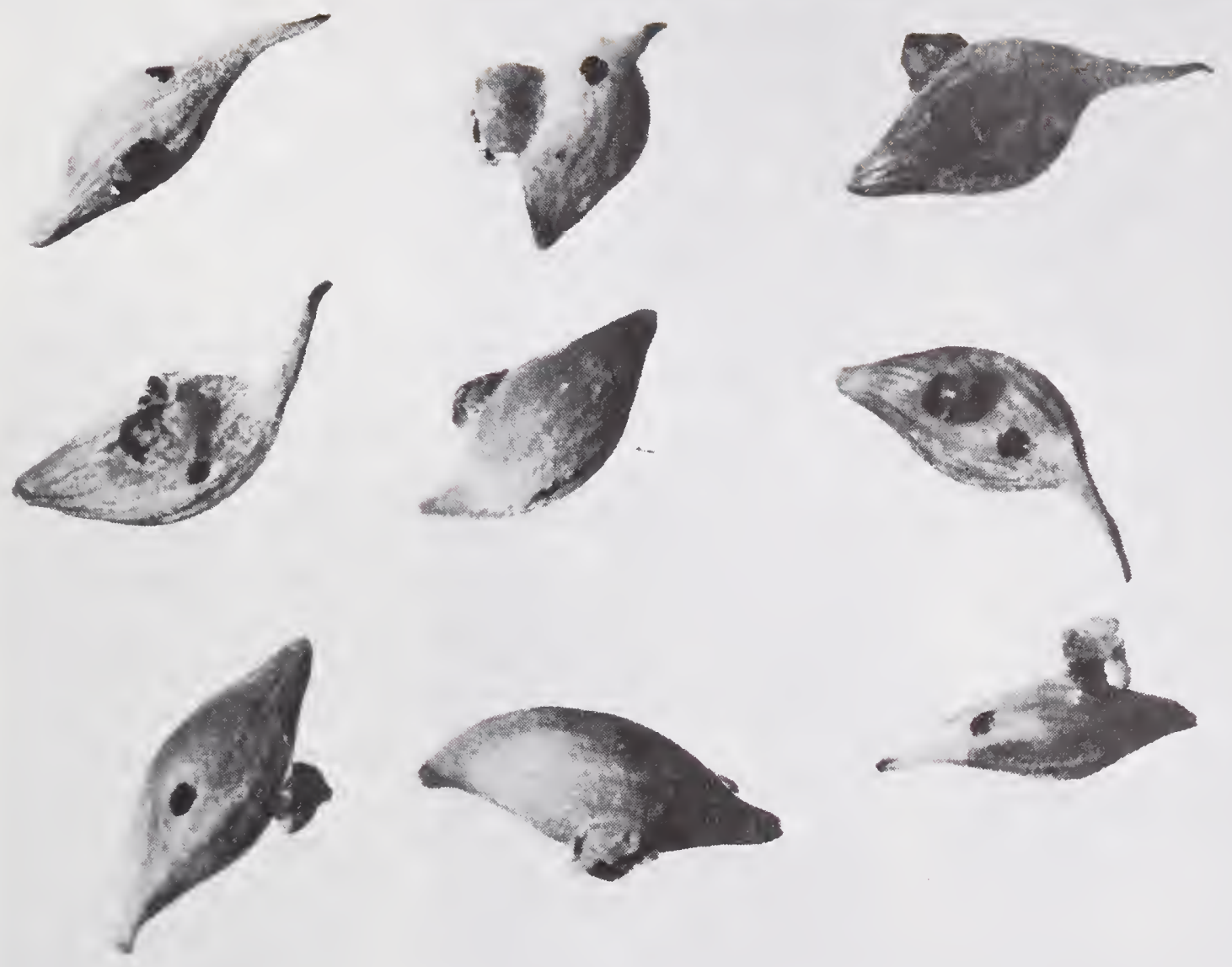

Figure 9.--Bitterbmush fruit domaged by mining of caterpillars of Filatima sperryi Clarke. The entry holes are plugged with silk secreted by the larvae.

LIFE CYCLE. Eggs are probably laid beginning in midAugust and winter is probably passed in this stage on the plant. Larvae are present from early June until early August when pupation occurs. Adults are in flight from mid-August until September.

\section{Reference}

Ferguson, R. B., M. M. Furniss, and J. V. Basile. 1963.

Insects destructive to bitterbrush flowers and seeds in southwestern Idaho. J. Econ. Entomol. 56:459-462.

\section{Gelechia mandella Busck: White-collared leaf tier}

RANGE AND HOST. Arizona, Idaho, Montana, and Alberta on Purshia tridentata (Pursh) DC. 
DAMAGE. First instar larvae mine seeds and destroy them. Later instars feed on leaves which are webbed together and retained on the plant. Infested plants are at their worst in appearance in late August. Damage was especially notable in Valley County, Idaho, during 1962 and in Ravalli County, Montana, in 1968. The long-term effect of damage by this leaf tier has not been assessed.

APPEARANCE AND HABITS. The egg has not been observed. Lamae range in size from $2 \mathrm{~mm}$ in the first instar to 12 $\mathrm{mm}$ when mature. The head and thoracic shield are shiny black. The mesothorax is bordered by two conspicuous white bands and the body is green with seven cream colored stripes muning lengthwise. Larvae of all instars have an anal comb consisting of two prominent recurved spines. First instar larvae mine seed (fig. 10); older larvae construct webs, open at both ends, through which they emerge to feed. When disturbed, larvae wriggle violently backward from their webs, and are sometimes called "nervous worms." The pupa is formed within a white cocoon on the plant. Wing span of the adult is 7 to $9 \mathrm{~mm}$. Background color of the moth is dark grayish brown. The front wings have three or four black dashes running lengthwise along their middle area. The trailing edges of both pairs of wings are feathery. The maxillary palps are hornlike and curve forward and upward from the underside of the head. Adults fly at night and are attracted to light.

LIFE CYCLE. Eggs are apparently laid during late August. The winter is probably passed in this stage but possibly small larvae may overwinter. Larvae have been collected from early June until early August, at which time pupation begins. Adults appear from mid-August to early September.

NATURAL CONTROL. Larvae are parasitized by a tachinid fly, Nemorizla sp., and braconid wasps, Agathis n.sp. and Chelonus sp.

\section{Geometridae: Measuringworms or Loopers}

\section{Anacamptodes clivinaria profanata (Barnes and McDunnough): Mountain mahogany looper}

RANGE. Easterm California, Oregon, Washington, British Columbia, Idaho, Utah, and western Colorado.

HOSTS. Cercocarpus Zedifolius Nutt. and Purshia tridentata (Pursh) DC. 
Figure 10.--A caterpizlar of Gelechia mandella Busck. beside bitterbrush fruit which it had infested.

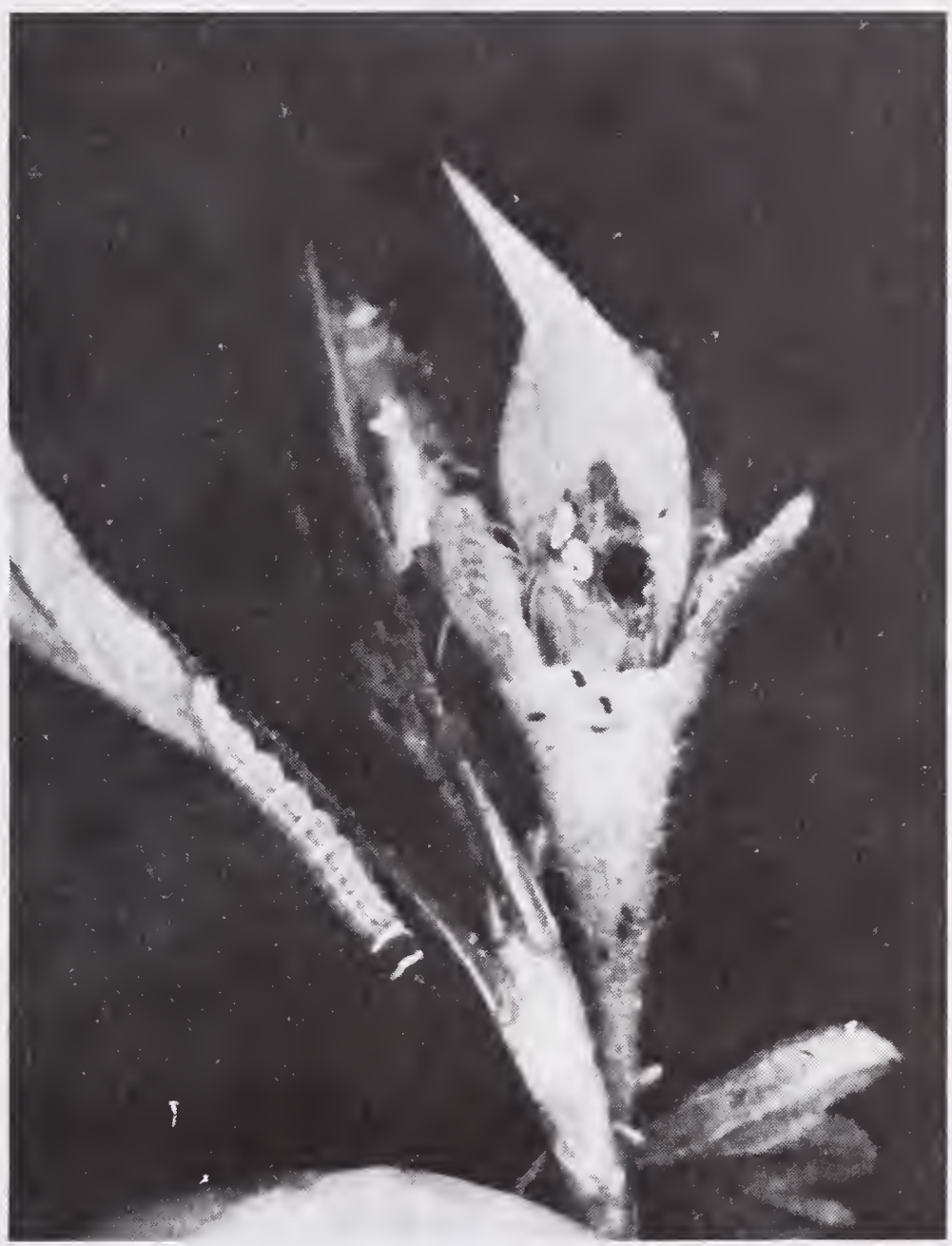

DAMAGE. Defoliation by the loopers (fig. 1lA) is capable of killing host plants extensively in relatively pure stands. In a 3-year outbreak, ending in 1964, loopers killed 50 percent of a 6,000-acre stand of mountain mahogany in southwestern Idaho. In 1957, they similarly killed bitterbrush in north central Oregon. Normally, they are present in small numbers and such destructive outbreaks are rare.

APPEARANCE AND HABITS. The green eggs are laid abundantly (70 to 716 per female) in crevices but are rarely seen. The larva (fig. 11B) is a typical looper and varies in length from 2.3 to $33.0 \mathrm{~mm}$ from the first to the fifth (last) instar. The larva's protective coloration and form, coupled with its habit of resting motionless in a crotchlike position, make it difficult to see. Color of larvae varies. On mountain mahogany, they tend to be marked with black against a cream, or sometimes orange-brown background. Larvae on bitterbrush are rather uniform gray. Pupation occurs in the soil beneath infested trees. The pupa is naked, stout, and shiny brown and has a four-tined spadelike process 


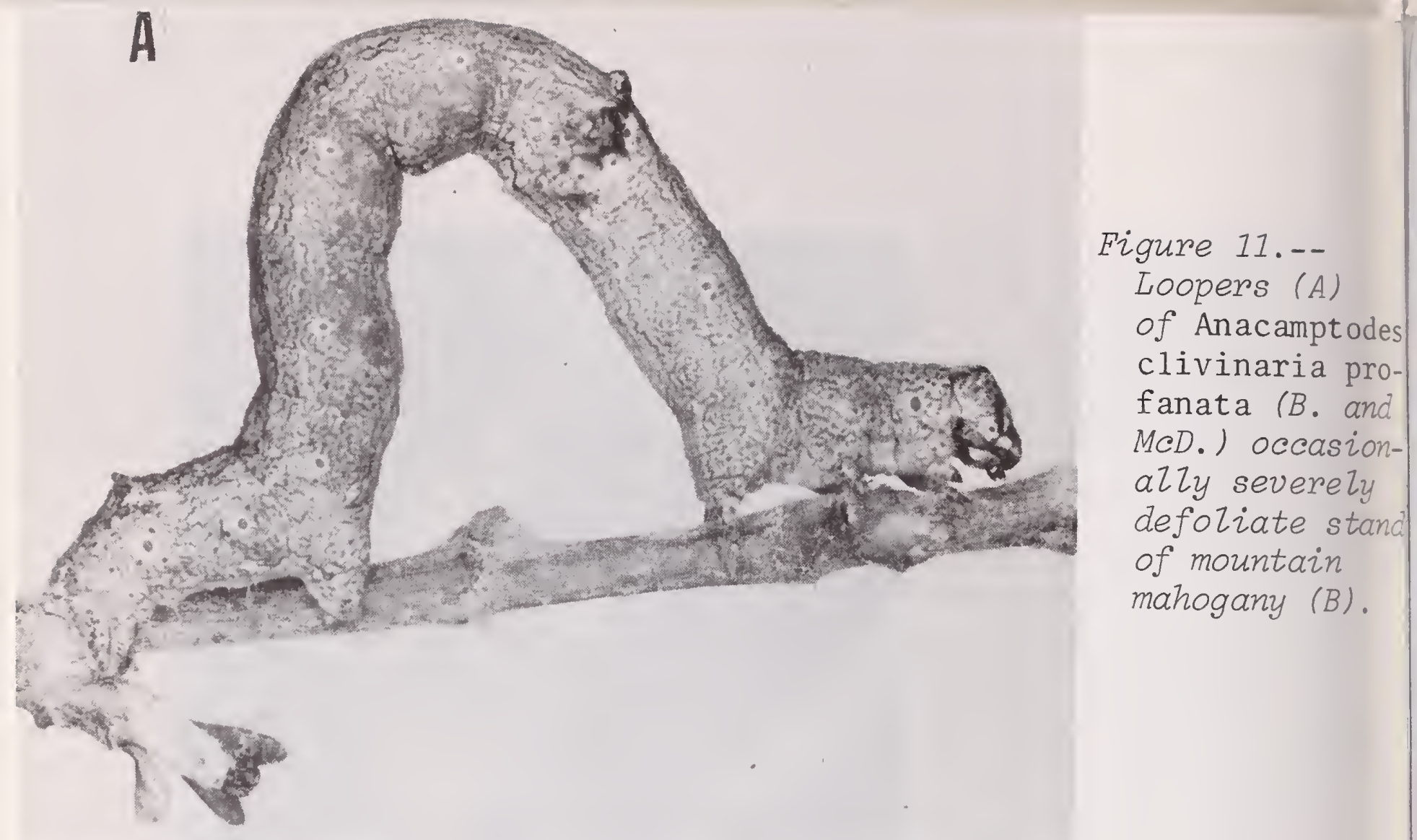


(cremaster) at its posterior. The adult moth is grayish with subdued black and brown markings. Males are somewhat more contrastingly marked, are more active, and have featherlike, rather than filamentlike, antennae. Wingspan is 27 to $36 \mathrm{~mm}$. In daytime they rest on the trunk of the host but are active at night.

LIFE CYCLE. Eggs are laid in June after adult moths emerge from the soil. The looper larvae appear from early July to mid-August, when they drop to the ground on silk threads to pupate in the soil and spend the winter.

NATURAL CONTROL. Parasites of the pupae include a tachinid fly, Btondelia (sp. n.?), an ichneumon wasp, Melanichneumon sp., and the pteromalid wasps, Tritneptis sp. and Cyclogastrella deplanata (Nees.). The first two named parasites seem rare; the others are more common and are multiple parasites; as many as 85 Tritneptis emerged from one host pupa. Starvation played a large part in the subsidence of an observed outbreak in southwestern Idaho.

\section{References}

Flake, H. W. 1964. Studies related to the control of Anacomptodes clivinaria (Guenée) (Lepidoptera: Geometridae). M.S. Thesis, Utah State Univ., 41 .

Furniss, Malcolm M. 1971. Mountain-mahogany looper. USDA For. Serv. For. Pest Leaf1. 124, 5 p.

Furniss, Malcolm M., and W. F. Barr. 1967. Bionomics of Anacomptodes clivinaria profanata (Lepidoptera:

Geometridae) on mountain mahogany in Idaho. Univ. Idaho Agric. Exp. Stn. Res. Bull. 73, 24 p.

Rindge, F. H. 1966. A revision of the moth genus Anacomptodes (Lepidoptera, Geometridae). Bu11. Am. Mus. Nat. Hist. $132: 17-243$.

\section{Lasiocampidae: Tent Caterpillars}

\section{Malacosoma spp.: Tent caterpillars}

RANGE AND HOSTS. Five species and 11 subspecies of these caterpillars occur on numerous kinds of shrubs and trees in the West. Three species are covered here. 
DAMAGE. Tent caterpillars cause severe defoliation resulting in decline of vigor accompanied by dieback of branches and up to 90 percent reduction of radial growth. Defoliation seldom occurs more than 2 or 3 years in succession but may kill the plants. The caterpillars are a nuisance in some recreational areas.

\section{GENERALIZED APPEARANCE AND HABITS. All species over-} winter in egg masses attached to the host plant. Hatching coincides with formation of the first new leaves. Larvae of several species build large tents (fig. 12A) in which they remain when not feeding. The larval stage lasts 4 to 8 weeks, depending on weather conditions. When larvae mature, they are 50 to $65 \mathrm{~mm}$ long and they lose their gregarious habit. Pupation occurs within silken cocoons (fig. 12B), spun on the host plant; cocoons are about 1 inch long and are dusted with white or yellowish powder. Adults appear 10 to 14 days after pupation and are active in the evening. Wingspan of males is 25 to $30 \mathrm{~mm}$; that of females is 30 to $35 \mathrm{~mm}$. The antennae of males are featherlike while those of females are filiform. Adults lack functional mouth parts and live only a few days.

\section{year. \\ LIFE CYCLE. Tent caterpillars have one generation per}

NATURAL CONTROL. Outbreaks are frequently reduced to a low level by nuclear polyhedrosis virus, by numerous species of parasites and predators, by starvation, and by prolonged unfavorably low temperatures. Among the parasites, the sarcophagid fly, Sarcophaga aldrichi Parker, is reported to have been important in suppressing $M$. distria in Minnesota.

\section{MaZacosoma distria Hubner: Forest tent caterpillar}

RANGE. Throughout the deciduous forests of the United States and Canada.

HOSTS. Nearly all species of deciduous trees are fed upon. Populus tremizoides Michx. is a preferred host but other species of Populus, as well as Quercus, Alnus, Salix, Betula, and Acer (except red maple) are also commonly defoliated

DAMAGE. Defoliation results in decline of tree vigor manifested by killing of branches and reduction of radial growth. In Minnesota, up to 80 percent of the aspen trees 
Figure 12.--Caterpizzars of

Malacosoma californicum (Packard) build tents (A) from which they forage for food on 100 shrubs including bitterbmush. Eggs are laid in a mass (B) encircling a stem.
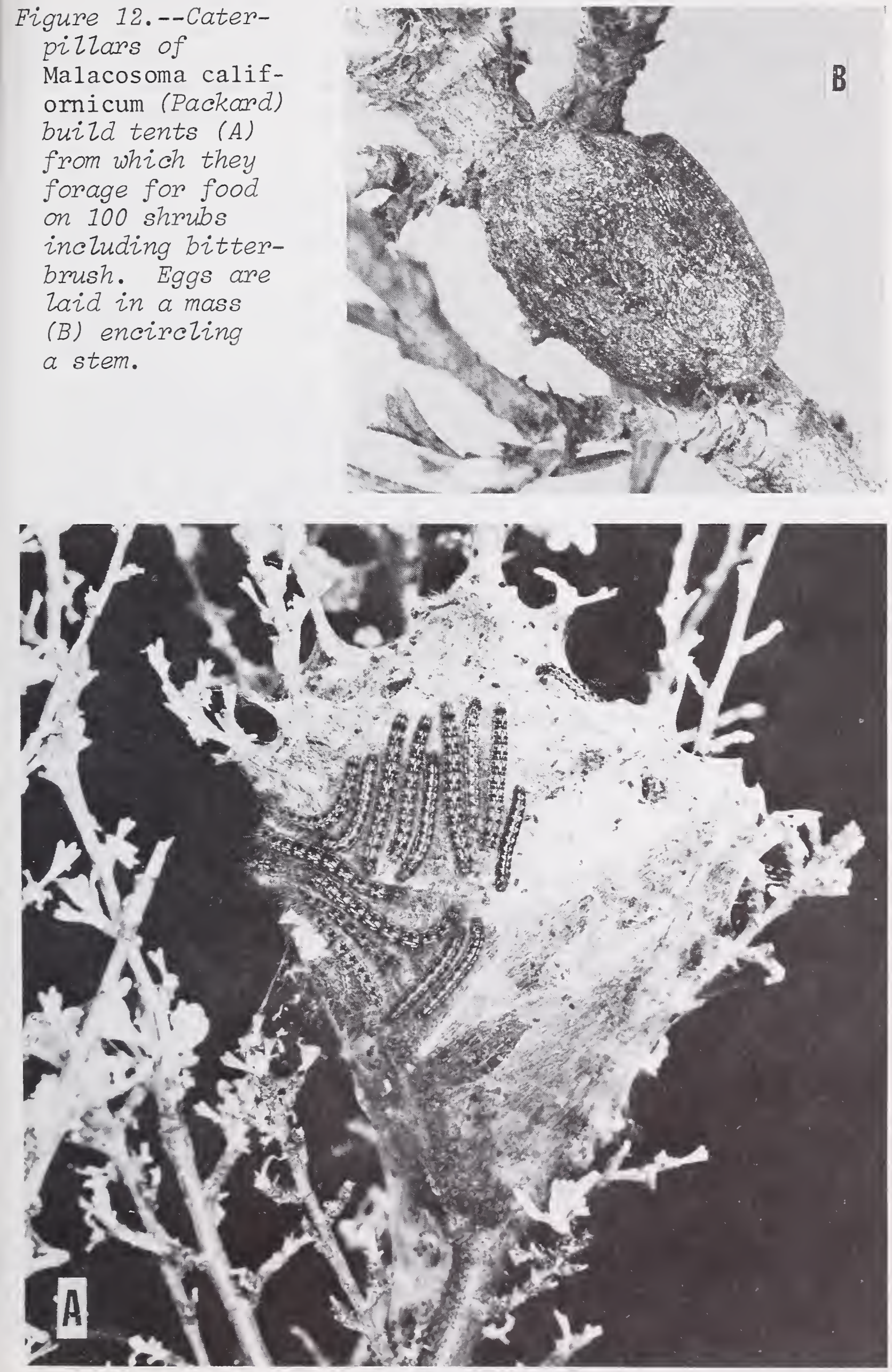
died following 4 or 5 years of repeated defoliation. Such prolonged outbreaks have not been reported in the West, but during 1963-64, especially severe defoliation occurred in the Idaho panhandle area where 116,000 acres of hardwoods were infested along river bottomland.

APPEARANCE AND HABITS. Eggs are laid in a helical mass of 100 to 350 eggs encircling a twig of up to one-half inch diameter. The egg mass is cylindrical with flattened ends and the eggs are cemented together with a frothy gluelike substance (spumaline), which is glossy dark brown. Newly hatched larvae are uniformly black and have conspicuous hairs. Mature larvae are blue, black, and gray with a somewhat keyhole-shaped dorsal spot on each segment, and with some yellowish or orange broken longitudinal lines. The caterpillars do not build silken nests but molt on thin mats of silk spun on branches. The cocoon is often spun between leaves and is suffused with a lemon-yellow powder. The adult is light buff brown and has a stout body. The forewings have two dark oblique lines near the middle.

\section{MaZacosoma califomicum (Packard): Western tent cater- pillar}

RANGE AND HOSTS. Throughout western and northern North America. Six subspecies are distributed around the periphery of a large central population. They include two subspecies (M. califomicum pluviale (Dyar) and M. califomicum fragile (Stretch) that were formerly considered to be separate species.

The central population of $M$. califomicum (Packard) occurs in a large heterogeneous area including most of the Great Basin, the Rocky Mountains within the United States, the mountains of the Southwest, eastern Oregon and Washington, and parts of northern California. It infests many hosts, including Purshia tridentata (Pursh) DC., Ceanothus, Salix, Cercocarpus, Rosa, Ribes, Amelanchier, Populus tremuloides Michx., and others. Particularly severe defoliation has been recorded on bitterbrush in the Great Basin, and on aspen at higher elevations in Colorado, New Mexico, Arizona, and Utah. In New Mexico, damage caused by caterpillars has prevented the growing of aspen commercially.

\section{M. californicum pluviale (Dyar) occurs west of the} Cascades in Oregon and Washington, and in the northern Rockies west of the Continental Divide, as well as in the boreal forests of Canada east to Quebec and in the northern fringes of the Lake States. Common hosts are Alnus, Salix, fruit trees, and various other Rosaceae. 
APPEARANCE AND HABITS. The highly variable life stages of this species make meaningful descriptions difficult. As a rule, any tent caterpillar found west of the Central Plains which builds a large tent is probably some form of M. califormicum unless it occurs along watercourses or at lower elevations in the Southwest where $M$. incumum is found. Eggs are laid in a mass partially encircling twigs and are covered with a grayish to brownish spumaline. The adult is basically yellowish to brownish with a pair of contrasting lines across the forewings.

Malacosoma constrictum (Henry Edwards): Pacific tent caterpillar

RANGE AND HOSTS. Western Washington and Oregon, Califormia, and Baja California. The subspecies $M$. constrictrom constrictum (Henry Edwards) occurs in the Pacific Northwest and to the San Bernardino and San Gabriel Mountains of California. It oviposits on Quercus and defoliates it, but the older larvae may feed on many other trees and shrubs.

APPEARANCE AND HABITS. Eggs are laid in a helical band completely encircling small twigs. The eggs are covered with bright yellow spumaline composed of large transparent bubbles. Mature larvae are predominantly whitish laterally and blue-white dorsally with no middorsal marks, but each segment has an hourglass-shaped dorsal orange blotch with a black spot on either side of the neck of the hourglass. Dorsal setae are orange and lateral setae are white; both are conspicuously tufted. Black markings are mixed with the other colors. Small tents are made by the larvae prior to molting. Cocoons are fairly tightly constructed, have no outer envelope of silk, and are dusted with a white powder. Adult males are usually light yellow, with wings crossed by two dark lines, the outline usually meeting the anterior margin at a right angle. Females are usually dark reddishbrown, dusted with whitish-yellow scales.

\section{References}

Churchil1, G. B., H. H. John, D. P. Duncan, and A. C. Hodson. 1964. Long-term effects of defoliation of aspen by the forest tent caterpillar. Ecology 45(3):630-633.

Clark, E. C. 1958. Ecology of the polyhedroses of tent caterpillars. Ecology 39:132-139. 
Duncan, D. P., and A. C. Hodson. 1958. Influence of the forest tent caterpillar upon the aspen forests of Minnesota. For. Sci. 4:71-93.

Franclemont, J. G. P. 72-85, in: Dominick, R. B., D. C. Fergus on, J. G. Franclemont; and others. 1973. The moths of America north of Mexico. Fasc. 20.1. Mimallonoidea; Bombycoidae (in part). E. W. Classey Ltd. and R. B. D. Publications, Inc., London.

Hodson, A. C. 1941. An ecological study of the forest tent caterpillar, Malacosoma distria Hübner, in northern Minnesota. Univ. Minn. Agric. Exp. Stn. Tech. Bull. $148,55 \mathrm{p}$.

Langston, R. L. 1957. A synopsis of the hymenopterous parasites of Malacosoma in California. Univ. Calif. Publ. Entomol. 14:1-50.

Stehr, F. W., and E. F. Cook. 1968. A revision of the genus Malacosoma Hübner in North America (Lepidoptera:

Lasiocampidae): systematics, biology, immatures, and parasites. U.S. Nat. Mus. Bu11. 276, 321 p.

Stelzer, M. J. 1967. Control of a tent caterpillar, Malacosoma fragile incuma with an aerial application of a nuclear-polyhedrosis virus and Bacizlus thuringiensis. J. Econ. Entomol. 60:38-41.

\section{Lymantriidae: Tussock Moths}

\section{Hemerocampa vetusta gulosa (Boisduval): Western tussock moth}

RANGE. California, Nevada, Oregon, Washington, Idaho, and British Columbia.

HOSTS. Purshia tridentata (Pursh) DC., Salix, Arctostaphylos, Quercus, and numerous kinds of fruit trees.

DAMAGE. The caterpillars feed on leaves and fruit, causing much damage. Healing of the feeding injury on young apples gives a scabby appearance and lowers their market value. During 1958-59 and 1963-64, extensive areas of bitterbrush were severely defoliated in the vicinity of Reno and Carson City, Nevada. Some twigs were killed. In 1957, this insect was 
rated as the most economically important orange-worm pest on citrus in California. In that year, approximately 10,000 acres of citrus were infested with caterpillars varying in number from 30 to 1,000 per tree. Within a 6-week period, heavy infestation may destroy all the new spring flush of growth and up to 80 percent of the newly set fruit.

APPEARANCE AND HABITS. The egg (fig. 13A) is $1.2 \mathrm{~mm}$ in diameter and is opaquely white. The shell is rather tough and is depressed at one end. Eggs are laid in closely matted, white, felty masses upon the old cocoons. The majority of egg masses are deposited on stems within a foot above ground. During oviposition, the female is atop the egg mass as though she were attempting to brood it or protect it as a hen would her eggs. The mature caterpillar (fig. 13B) attains a maximum length of $22 \mathrm{~mm}$ and is black with numerous bright red and yellow tubercular spots; each red spot is the source of long, radiating gray-white hairs. There are four median-dorsal tufts, uniform honey color or whitish, sometimes tipped with black, and two long anterior black tufts and one posterior black hornlike tuft. When small, the hairy caterpillars are dispersed by wind. The cocoon is loosely composed of grayish-white silk and incorporates many of the larval hairs. The male pupa is $12 \mathrm{~mm}$ long, glossy, translucent brownish black, with the wing pads coming down to the abdominal segments, and the conspicuous featherlike antennae curving down from the head like a ram's horns. The female pupa is about 16 $\mathrm{mm}$ long, glossy, translucent light yellowish brown, with shorter wing pads and less conspicuous antennae; the short airlike antennae curve down and parallel the palpi. The female moth is 12-15 mm long when gravid but much smaller after oviposition has occurred. She lacks the ability to fly, having only rudimentary wings. Her integument is glossy black and is almost completely covered with long, wavy pinkishgray hair. The adult male is winged, with an expanse of 20 to $27 \mathrm{~mm}$. It is generally brownish with grayish-white and dark brown markings. At rest, its wings form a triangular outline from above.

LIFE CYCLE. A single generation occurs per year in most locations, although there may be two in southern California. Depending on climate of the area, adult moths are present from May through July, during which time eggs are laid. In Idaho and Nevada, eggs are laid only in July.

NATURAL CONTROL. The eggs are parasitized by two wasps: ooencyrtus catifornicus Girault (Encyrtidae) and Telenomus 


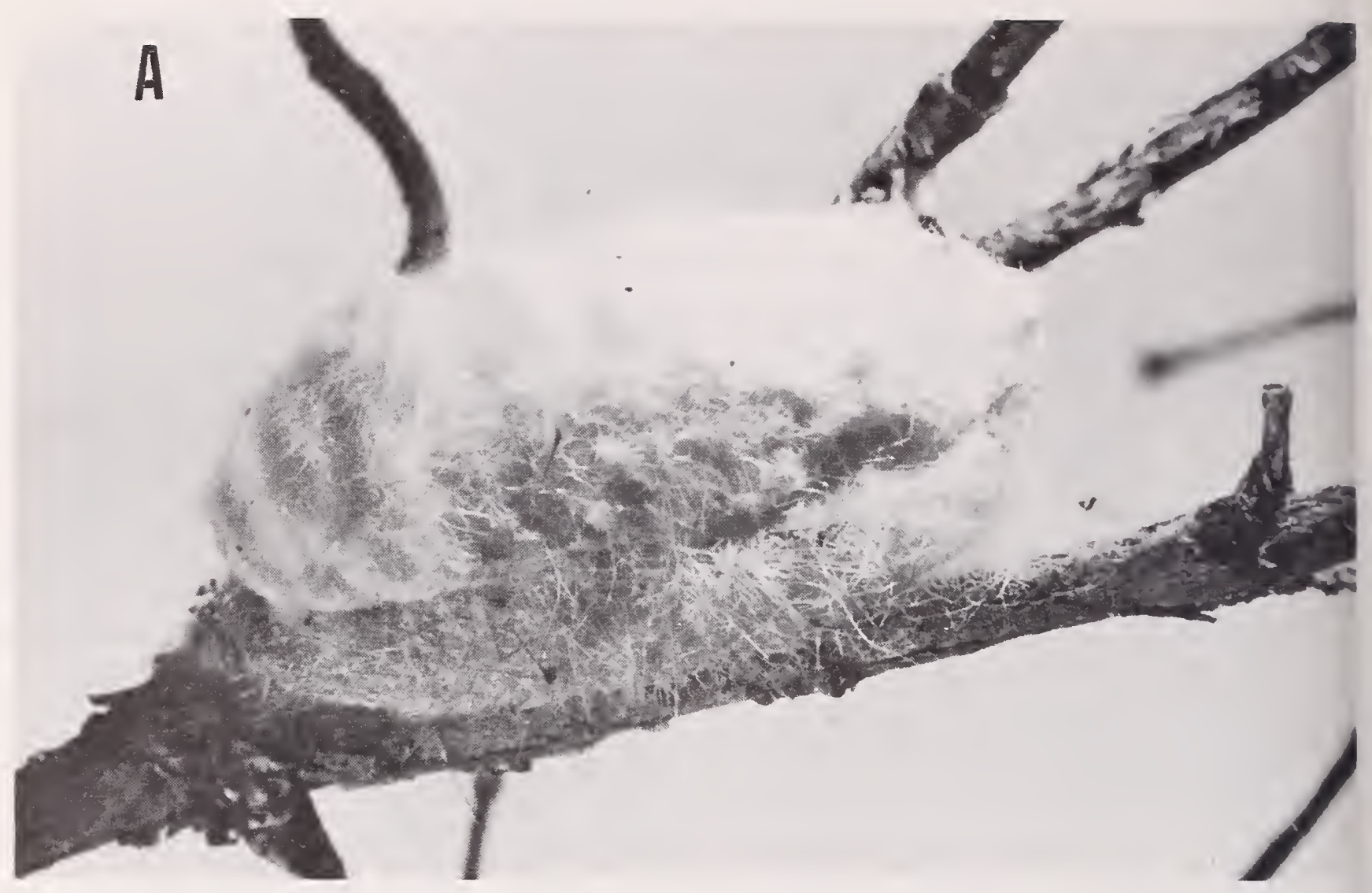

Figure 13.--The westem tussock moth overwinters in egg masses (A) attached to Ceanothus velutinus and other shmbs. The hairy caterpizlars (B) are disseminated by wind when very young.

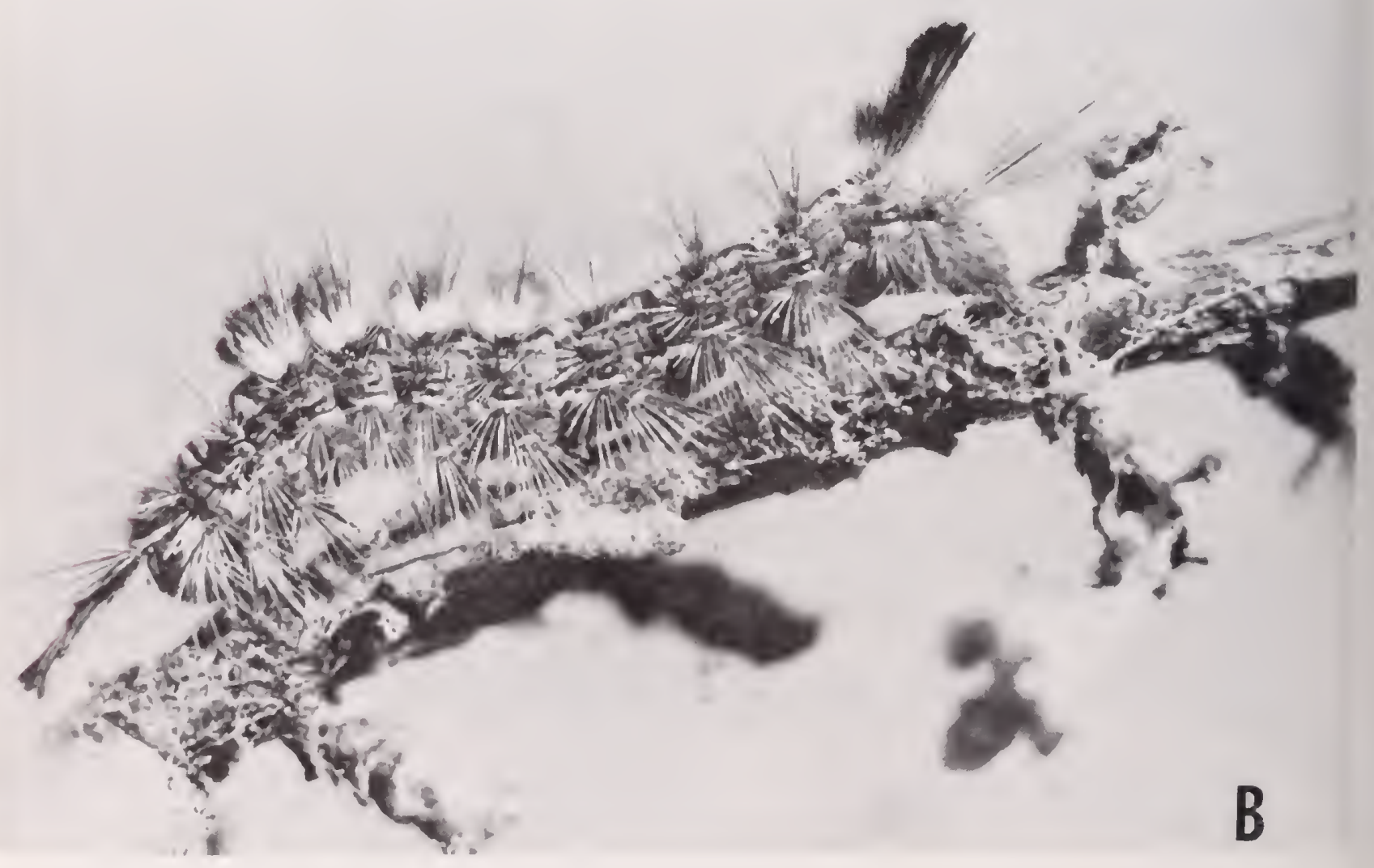


sp., prob. californicus Ashm. (Scelionidae), and preyed on by a beetle, Trogoderma stemale Jayne var. (Dermestidae). Larvae are parasitized by three ichneumon wasps: Iseropus orgyiae (Ashw.), Coccygomimus sanguinipes (Cress.), and Phobocampe sp.; a braconid wasp, Bracon xanthonotus Ashm.; a pteromalid wasp, Brachymeria ovata abiesae (Gir.); and a tachnid fly, PatelZoa fusscimacula Ald. and Webb. Pupae are preyed on by the anthocorid bug, Lyctocoris compestris (F.).

\section{References}

Atkins, E. L. 1958. The western tussock moth, Hemerocompa vetusta (Bdv.), on citrus in southern California. J. Econ. Entomol. 51:762-765.

Brown, L. R. and C. O. Eads. 1965. A technical study of insects affecting the oak tree in southern California. Calif. Agric. Exp. Stn. Bul1. 810, 105 p. (see p. 41-44).

Furniss, Malcolm M., and J. A. E. Knopf. 1971. Westem tussock moth. USDA For. Serv. For. Pest Leaf1. 120, $4 \mathrm{p}$.

Volck, W. H. 1907. The California tussock-moth. Univ. Calif. Agric. Exp. Stn. Bu11. 183:189-216.

\section{Nymphalidae: Brush-footed Butterflies}

\section{Nymphalis antiopa Linnaeus: Morning-cloak butterfly}

RANGE. Widely distributed; occurs throughout much of the Northern Hemisphere.

HOSTS. Mainly Salix, UZmus, and species of Populus (especially $P$. tremuloides Michx.) but also recorded on Betula, Alnus, Acer, and rarely other trees.

DAMAGE. The newly hatched caterpillars skeletonize leaves but larger caterpillars devour all except the midrib. Occasionally, very severe defoliation occurs locally.

APPEARANCE AND HABITS. The orange-brown eggs are subcylindrical, ribbed, and rounded at their ends. They are laid in clusters of 20 or more, encircling a twig. The caterpillar (fig. 14) is black with short pale hairs and numerous long black forked spines. A single row of rich red 


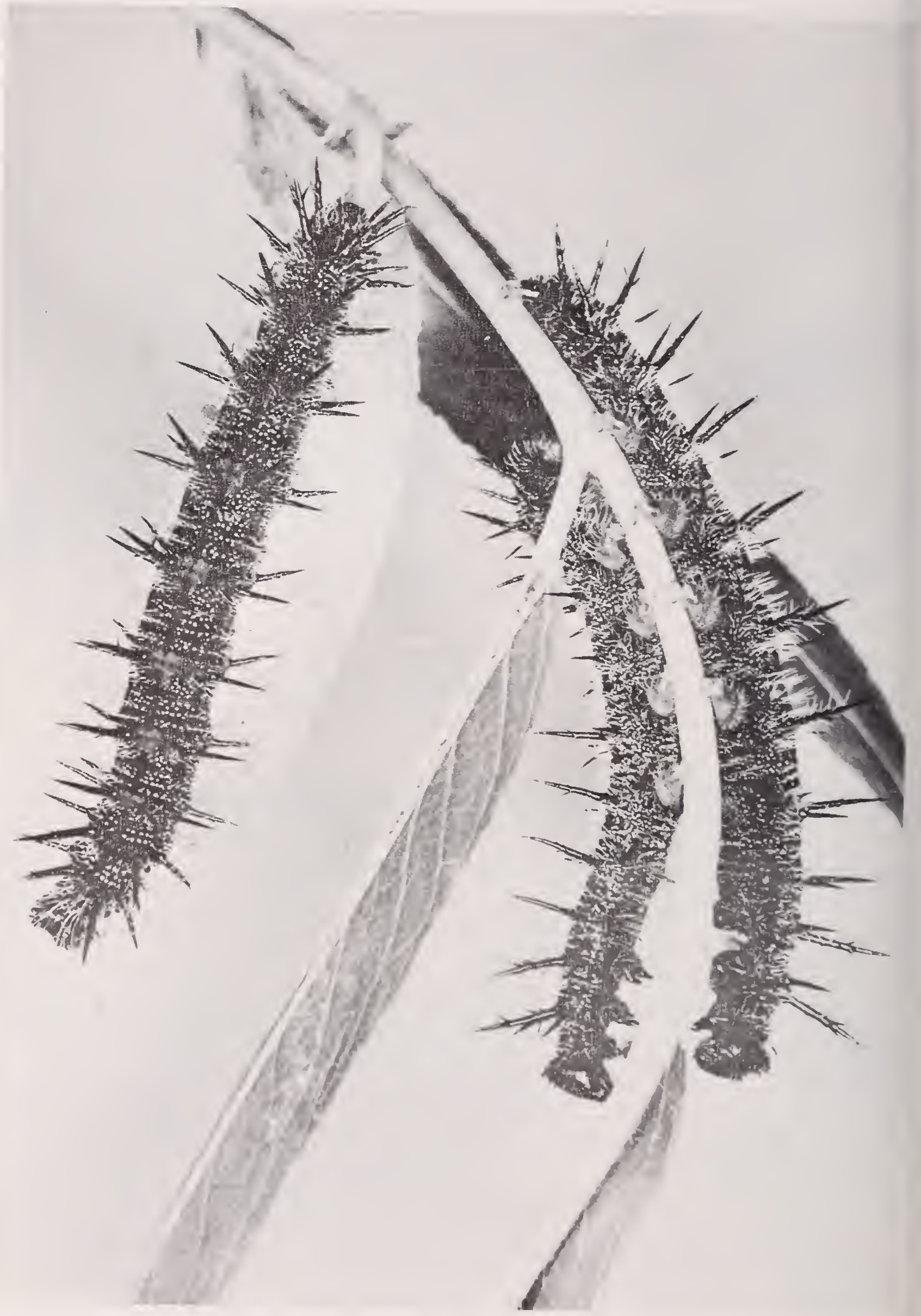

Figure 14.--Caterpilzars of the mouming-cloak butterfly feed gregariously on willow leaves. Their prominent spines provide them protection against some enemies. 
spots extends down the center of the back of the abdomen. The head of the caterpillar is round, black, and hairy. The thoracic legs are shiny black and the claspers on the prolegs are dull red. Newly hatched larvae feed side by side, with their heads toward the margin of the leaf. A silk thread is deposited by the caterpillars as they travel from leaf to leaf, making a sort of carpet. Eventually, this webbing becomes conspicuous and may bind together neighboring twigs. The pupa is 22 to $25 \mathrm{~mm}$ long, brown with gray or purple bloom, and its shape resembles that of the California tortoiseshell (see below). Like that species, the pupa hangs head downward, attached to the plant by silk to which it anchored its anal claspers while still a larva. Wingspan of the beautiful purple-black butterfly is 50 to $70 \mathrm{~mm}$. The outer edges of the wings are bordered with a yellow stripe inside of which is a row of blue or purple spots. Two yellow spots occur toward the tip on the leading edge of the forewings.

LIFE CYCLE. Though the occurrence of multiple broods has been suggested, one generation per year seems to be normal over much of its range. The butterfly hibermates overwinter and appears in flight on sunny days during spring. Eggs are found during May and June, hatching in about 2 weeks. In northern areas, the caterpillars appear throughout the summer and pupae begin to appear in late June. Duration of the larval and pupal stages of an individual averages 4 and 2 weeks, respectively.

NATURAL CONTROL. Eggs of the mourning-cloak are parasitized by the scelionid wasp, Teleonomus graptae Howard. Other wasps that parasitize caterpillars are reported to include the ichneumons, Itoplectis conquisitor (Say) and Hoplismenus morulus momilus (Say); the pteromalids, Pteromalus fuscipes (Provancher), P. pupamum (Linnaeus), and $P$. vanessae Harris; and the chalcids, Brachymeria compsizurae (Crawford), and B. ovata ovata (Say).

\section{Reference}

Weed, C. M. 1899. The spiny elm caterpillar. New Hampshire Col1. Agric. Exp. Stn. Bul1. 67:123-141.

\section{Nymphalis californica (Boisduval): California tortoise-shell}

RANGE. Throughout the Western United States; occasionally overwinters on Vancouver Island, British Columbia. 
HOSTS. Most often, snowbrush (Ceanothus velutinus) and mountain whitethorn ( $C$. cordulatus), but also recorded on Amelanchier, Salix, Arctostaphylos, wild lilac, other shrubs, and alfalfa.

DAMAGE. Destructive outbreaks have occurred on Ceanothus in many localities in northern California, especially during 1911, 1932, and 1951. In 1959, the caterpillars severely defoliated snowbrush in the Cascade Mountains of Oregon and, in 1959 and 1961, locally severe damage occurred in southwesterr Idaho.

APPEARANCE AND HABITS. The eggs are thought to be laid in a cluster, encircling a twig, as are those of $N$. antiopa. The caterpillar attains a length of 23 to $35 \mathrm{~mm}$ when mature. It is black with fine-branched spines on each segment. Down the middle of the back is a row of bright yellow spines mounted in blue tubercles, between which are numerous yellowish dots. The naked pupa (fig. 15) is 20 to $22 \mathrm{~mm}$ long, resembling a serrated crescent in shape, and with a rather shiny brown surface. It hangs downward, headfirst attached to a branch by silk and its anal claspers. Stout points arise from the dorsal and lateral surfaces and from the front of the head. A sharp constriction between the thorax and abdomen contributes to a triangular shape of the forebody in lateral view. When disturbed, pupae thrash wildly from side to side. The butterfly (fig. 15) has a wingspan of 50 to $65 \mathrm{~mm}$. Its color is brown and deep brown above, distinctly marked with black spots and border. The hind wings have a single large basal black spot and a submarginal row of purple spots. The undersurface is marbled fawn and various shades of brown with a narrow irregular submarginal purple line on both pairs of wings. During migration to and from its winter hibernation sites it has often attracted attention. One observer estimated that 600 butterflies per minute passed between two trees 50 feet apart.

LIFE CYCLE. There is a single generation per year. Eggs are laid in spring by adults that have hibernated overwinter. Larvae are present until the latter part of June to mid-July, at which time they pupate. Migrating adults begin to appear in late July and are abundant in early August.

NATURAL CONTROL. A multiple pteromalid parasite, Pteromalus vanessae How., commonly destroys pupae in Idaho. In California, adults have reportedly been fed on by the Brewer 


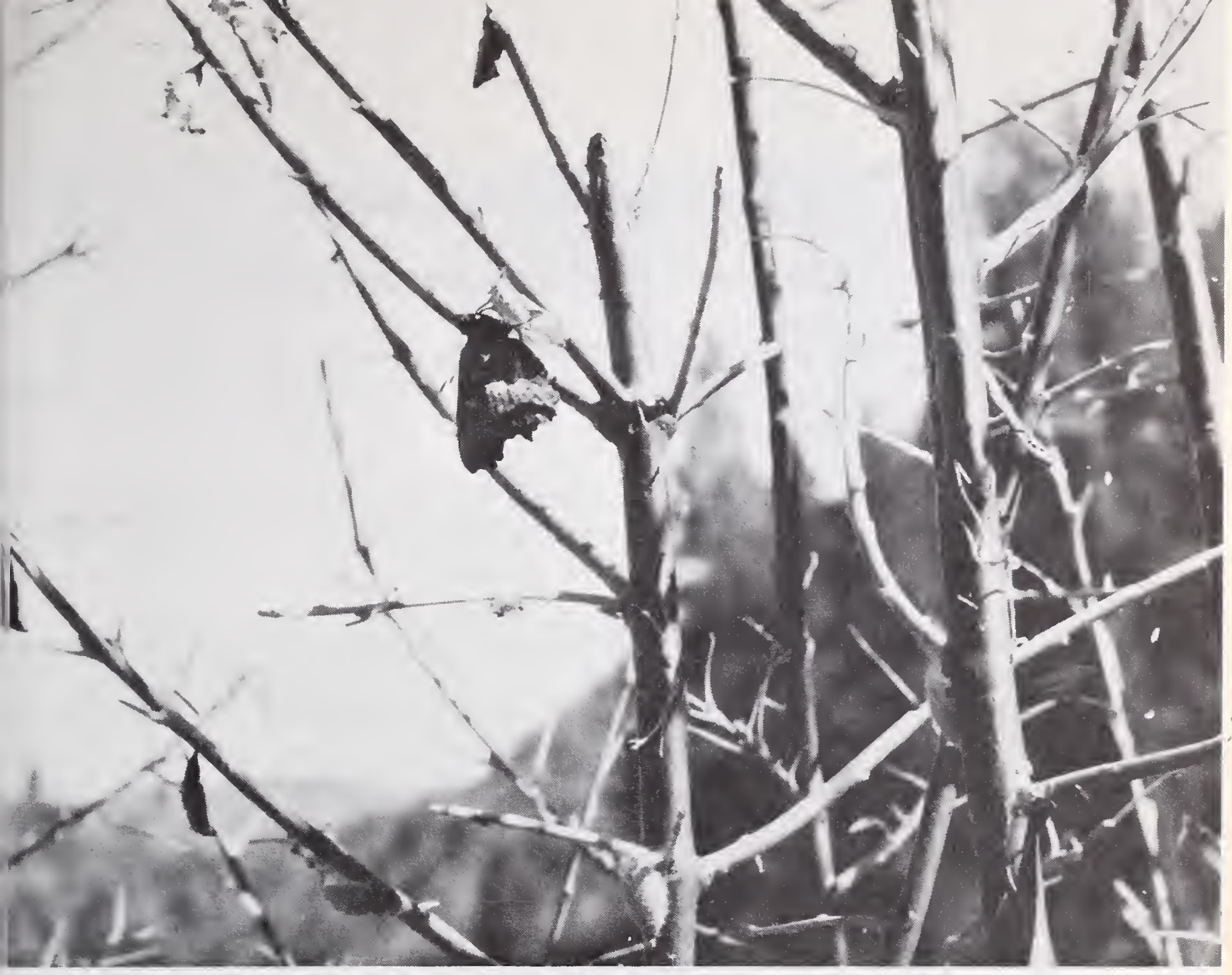

Figure 15.--A freshly emerged adult California tortoise shell butterfly hangs from its chrysalis on a defoliated shrib. Other chrysalids, and pupae, hang head downward from the branches.

blackbird, and caterpillars are eaten by ants and goldenmantled ground squirrels. Chipmunks have been seen eating the pupae. Severe hailstorms in the mountains during late summer probably take a toll of the migrating butterflies.

\section{References}

Bryant, H. C. 1911. The relation of birds to an insect outbreak in northern California during the spring and summer of 1911. Condor 13:195-208.

Essig, E. 0. 1956. Insects of western North America. 1035 p. MacMillan Co., New York.

Storer, T. I. 1933. Aglais califomia in California during 1932. Pan-Pac. Entomol. 9(2):67-68.

Tevis, L., Jr. 1953. An outbreak of Nymphalis califomica near Lake Almanor, California. Pan-Pac. Entomol. $29(4): 201-202$. 


\section{Psychidae: Bagworm Moths}

\section{Apterona crenufella (Bruand) form helix: Snailcase bagworm}

RANGE. Native to Europe; first found in the United States (in California) in 1940 and now occurs also in Nevada, Utah, and Idaho.

HOSTS. Artemisia tridentata Nutt., Cercocarpus ledifolius Nutt. and species of Chrysothomnus, Salix, Atriplex, and Prunus as well as many other plants.

DAMAGE. The most notable outbreak of this defoliator occurred in Box Elder County, Utah, during 1950-55, when 5,000 acres of rangeland were severely damaged. Substantial areas elsewhere in that State have also experienced outbreaks of the bagworm. In California, some commercial crops have been considerably damaged when populations were high. For example, 55 percent of the leaf surface of garden plants and 20 percent of the leaf surface of apple trees have been destroyed in local areas. At first, feeding by larvae creates concavities $1 / 32$ - to $1 / 16$-inch diameter on either leaf surface. These increase to one-eighth inch as the larvae grow. Additionally, larvae feed outward from these openings, creating a cavity between the leaf surfaces averaging one-fourth by three-eighth inch.

APPEARANCE AND HABITS. The egg is pale yellowish white, soft shelled, and somewhat elongate. From 10 to 30 eggs are laid per female. Newly hatched larvae are about $1 \mathrm{~mm}$ long, increasing to 6 to $7 \mathrm{~mm}$ at maturity. Larvae are greenishto reddish-gray with similar colored thoracic and anal plates. The head is nearly black. The thorax is robust, being at least twice the diameter of the tip of the tapered abdomen. The thoracic legs are very strong whereas the prolegs are reduced to crotchets and are nonfunctional. The larva is curled in shape. The snail-like case (fig. 16) is constructed by the larva with silk and soil particles. It contains a lateral opening in the upper whorl through which fecal matter is extruded. The case is held upright and the larva moves about with the forepart of the body projecting from the case. The pupa is 5 to $6 \mathrm{~mm}$ long, curved in a gentle spiral form, yellowish-brown and slightly diminished anteriorly. Only parthenogenetic females appear to have been introduced into the United States, although males occur in Europe. The adult female moth is wingless, nearly legless, and without functioning mouth parts, antennae or faceted eyes. She is in fact merely 
Figure 16.--Snail-like cases containing Zamae of Apterona crenulella (Bmand) on bitterbrush.

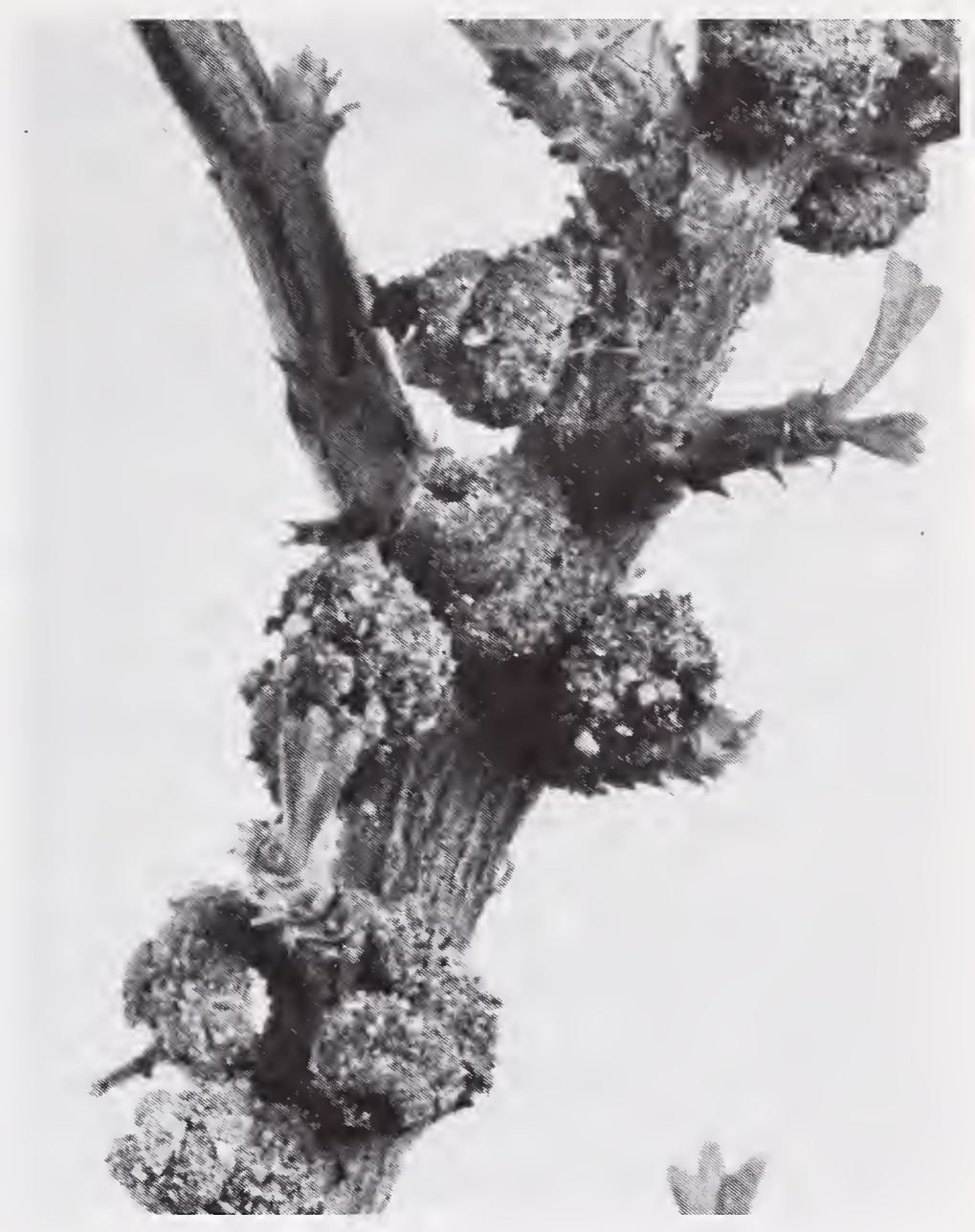

a specialized egg-laying device. Her body is 5 to $6 \mathrm{~mm}$ long, curved in a spiral form, and gray with brownish dorsal area. Sparse white hairs occur on the body with more dense lateral tufts near the tip of the abdomen.

LIFE CYCLE. The bagworm has one generation per year. Larvae overwinter within the pupal skin of the parent. They emerge to begin feeding in mid-April. During July, they seek out high points (fenceposts, buildings, and trees) on which to attach themselves over winter. Pupation, transformation to the adults, and reproduction all occur during July. Eggs hatch within 3 weeks.

\section{References}

Robinson, D. 1953. Garden bagworm, Apterona crenulella (-Helix) in Nevada and Placer Counties, California. The Bulletin, Calif. Dep. Agric. 42:1-9.

Kozhanchikov, I. V. 1956. Fauna of the U.S.S.R. Lepidoptera. Psychidae. Vol. III, No. 2. Zool. Inst. Acad. Sci. U.S.S.R., 525 p. (see p. 462-465). U.S. Dep. Commerce Transl. TT 69-55058. 


\section{Saturniidae: Giant Silkworm Moths}

\section{Hemileuca spp.: Buck moths and day moths}

The taxonomy of these moths is confused and their biology is not well known. Four of the better known species are described below.

APPEARANCE AND HABITS. Fggs are deposited in masses encircling a stem of the host plant. The larvae feed in colonies but do not spin tents. When caterpillars are numerous, plants are completely stripped of foliage. The caterpillars are mostly black, with various yellow or red markings depending on the species. Numerous branched urticating spines cause painful welts on contact with humans and severely inflame the mouths of livestock if ingested. Some species of Hemileuca spin a loose cocoon on the plant or in plant litter, but those referred to by some as Pseudohazis pupate in loose soil without a cocoon. Adults may hang in clusters on plants. Most species (including all = Pseudohazis) are day-flying moths with main flights occurring early in morning or late in afternoon.

LIFE CYCLE. Species that occur in warmer areas, such as Hemileuca eglanterina (Boisduval) (=Pseudohazis) in California, have one generation annually. The winter is spent as a first instar larva within the egg. Larval feeding occurs during spring and summer. Pupation occurs in late summer and the adult moth emerges and oviposits in the fall. Species such as Hemileuca hera Harris (=Pseudohazis) that inhabit cooler areas, have a 2-year life cycle. They hibernate as a first instar larva within the egg during the first winter, and as a pupa during the second winter. Adults are present generally from mid-July through August.

Hemileuca nevadensis Stretch: Nevada buck moth

RANGE. New Mexico, Arizona, California, and Idaho.

HOSTS. Mainly willow and poplar but may include a number of other deciduous trees and shrubs. Damage is sometimes severe locally.

APPEARANCE. This moth has a white wing band occupying about half of the total wing area. Wingspan is 70 to $75 \mathrm{~mm}$. 
Hemileuca eglanterina (Boisduval) (=Pseudohazis): Pacific day moth.

RANGE. Subspecies egZanterina--California, Oregon, Washington, British Columbia, Montana, and northwestern Wyoming. Subspecies shastaensis (Grote)--limited to the southern part of the Cascade Mountains. The caterpillars cause economic damage to range shrubs and cultivated plants.

HOSTS. Ceanothus preferably; larvae feed on a wide variety of plants including Salix, ArctostaphyZos, Prunus, Rosa, and fruit trees.

APPEARANCE AND HABITS. The moth has a wing expanse of 65 to $75 \mathrm{~mm}$. Wings are yellow with conspicuous black markings including an eye-spot and an erratic outer band. A golden yellow stripe extends from the eye-spot of the front wing toward the margin. Moths appear in fall and fly in daytime. Eggs are orange color. The first instar larvae remain inside the eggs over winter and emerge in spring. Mature caterpillars are 50 to $60 \mathrm{~mm}$ long, dark brown, or dull black, with reddish dorsal spots and a narrow red line on each side. They are covered with stout, many branched, black and tan spines. Pupation occurs in plant litter.

NATURAL CONTROL. Larvae are parasitized by an ichneumon wasp, Apanteles electrae Vier.

Hemileuca hera hera (Harris) (=Pseudohazis): Great Basin day moth

RANGE: Throughout the Great Basin from the eastern slope of the Sierra Nevada to the Rockies, and from the Snake River into Arizona and New Mexico.

HOSTS. Symphoricarpus, which is often completely defoliated in areas of northern Utah; also commonly Artemisia.

APPEARANCE. The color of this moth is usually a rather clear, contrasting golden yellow and black, but white and black variations also occur. Near its eastward limit a very dark form predominates. It differs from $H$. eglanterina by lacking a golden stripe between the eye-spot and wing margin. 
Hemileuca nuttalli nuttalli (Strecker) (= Pseudohazis): Nuttall's day moth

RANGE. From the Snake River northward in Idaho and eastward into western Wyoming and Montana.

HOSTS. Artemisia, preferably, which it often severely defoliates in the area south of West Yellowstone.

APPEARANCE. The forewings are basically lavender and black while the hind wings are golden yellow and black. A yellow stripe similar to that of $H$. eglanterina extends from the front eye-spot.

\section{References}

Essig, E. O. 1956. Insects of western North America. 1035 p. MacMillan Co., New York. (see p. 670-672)

Ferguson, Douglas C. 1971. In: Dominick, R. B., D. C. Ferguson, J. G. Franclemont, et al. The moths of America north of Mexico. Fasc. 20.2A. Bombycoidea. Saturniidae (Part). 153 p. E.W. Classey Ltd. and R.B.D. Publications, Inc., London.

\section{Tortricidae: Leafroller Moths}

\section{Synnoma lynosyrana Walsingham: Rabbitbrush webbing moth}

RANGE. Discontinuous in rangeland areas of the West. It is $\overline{\text { known }}$ from northern California, Idaho, Nevada, Utah, Arizona, Montana, Colorado, and New Mexico.

HOSTS. Chrysothomnus nauseosus (Pall.) Britt. and C. viscidifloms (Hook.) Nutt.

DAMAGE. Defoliation by this insect is usually confined to local situations and rarely results in extensive plant mortality. Observations made in southerm Idaho indicate that infestations can cause partial killing and weakening of plants, especially green rabbitbrush.

APPEARANCE AND HABITS. Eggs are spherical, laterally flattened, about $0.4 \mathrm{~mm}$ in diameter, black with a somewhat granular surface. They are deposited in two-row masses in an overlapping fashion with approximately 100 eggs per mass. 
They are most commonly located on small twigs or grass and debris on or at the base of the host plant. The larva is cream-colored, not conspicuously hairy, with the head and prothoracic shield brown. The mature larva is 18 to $24 \mathrm{~mm}$ long. The young larvae web leaves together and feed within the small webbing mass. As the larvae mature, more leaves as well as branches are webbed together. Six or more main stems may be enclosed in a webbing mass which can contain the webbing tunnels of up to eight larvae. The pupa is dark brown, $8-1 / 2$ to $17 \mathrm{~mm}$ long. Pupation occurs in the webbing mass. Adults emerge only in the early morning and are active only during the day. Most of the body and wings are covered with orange to brown scales and hairs that are intermixed with white and black scales. Some of the dark scales on the wings are erect. The abdomen is black. The wing expanse is 15 to $22 \mathrm{~mm}$. Gravid females are unable to fly.

\section{LIFE CYCLE. Eggs overwinter and hatch in the early} spring. Larvae are active throughout the spring and summer and pupation occurs from mid-August to mid-October and lasts approximately 6 weeks. Adults begin to emerge in late September and have been found active in the field as late as early November.

NATURAL CONTROL. Seven species of parasites have been found associated with the rabbitbrush webbing moth. The most important appear to be Trichogroma minutum Riley which is associated with the eggs and Glypta sp. and Dibrachys cavus (Walk.) which have been reared from the larvae.

\section{Reference}

Hawkes, R. B. 1962. Biology of Synnoma Zynosyrana Walsingham in Idaho (Tortricidae: Lepidoptera). M.S. Thesis, Univ. Idaho, $51 \mathrm{p}$.

\section{THYSANOPTERA: THRIPS}

\section{Thripidae: Common Thrips}

\section{Frankliniella occidentalis (Pergande): Western flower thrips}

RANGE. Throughout western North America from sea level to subalpine altitudes. 
HOSTS. Include Purshia tridentata (Pursh) DC.; nearly every flowering plant may be infested, especially the Leguminosae, Compositae, and Crucifera.

DAMAGE. This thrips enters bitterbrush flower buds and feeds on the developing parts of the flowers. Damage at this stage may prevent formation of some seed.

APPEARANCE AND HABITS. The opaque, reniform egg is inserted in the parenchyma cells of leaves, flower parts, and fruits. It hatches in 6 days at room temperature. The tiny first instar nymph emerges from the surface of the plant tissue headfirst and molts in about 3 days. The active second instar nymph is golden yellow. After about 6 days the nymph undergoes two quiescent stages (pseudopupa). These last about a week and terminate in the adult stage. Adults vary in color, there being a pale form which is mostly white and yellow; an intermediate form which has an orange thorax and a brown abdomen; and a dark brown form. They are slender and about $1 \mathrm{~mm}$ long, with the wings narrow, fringed, and usually inconspicuous. They are secretive and seek the seclusio provided by flowers. Their capacity to fly is limited. The adult initiates flight by first arching its abdomen upward. It then spreads its wings and releases its grip, causing it to be propelled end over end. It readily catches fast to whatever it strikes. The females reproduce either parthenogenetically, when they produce only males, or by mating with males.

LIFE CYCLE. Numerous generations occur annually, influencer greatly by climate. In areas having a cold winter, the overwintering population tends to be adult females. A large increase in numbers of thrips occurs in spring with the resumption of warm weather and blossoming.

\section{Reference}

Bryan, Douglas E., and Ray F. Smith. 1956. The Frankliniella occidentalis (Pergande) complex in California (Thysanoptera: Thripidae). Univ. Calif. Pub1. Entomol. $10: 359-410$. 


\section{IMPORTANT MITES}

\section{ACARINA: MITES AND TICKS}

\section{Eriophyidae: Gall Mites}

\section{Aceria kraftella Keifer: Bitterbrush stem gall mite}

RANGE. California, Nevada, Oregon, Idaho, Montana, and British Columbia.

\section{HOST. Purshia tridentata (Pursh) DC.}

DAMAGE. Infestation by the mite causes irregular galls to form on current-year stems. Although the galls deform the branches (fig. 17), they are seldom abundant. The possibility that infestation kills stems or causes them to become diseased has not been verified.

APPEARANCE AND HABITS. The immature stages and the mite's habits have not been described. The mites can be observed only under magnification. They are minute (less than $0.3 \mathrm{~mm}$ long), and lack coloration, and have only two pairs of legs at the anterior end. The abdomen is elongated, finely striated with concentric lines, and terminates in two long spines.

LIFE CYCLE. The life cycle has not been studied. Other eriophyid mites have immature and adult stages present over winter and a number of uneven broods resulting from continuous breeding during summer. The mite apparently emerges from stem galls in spring and infests new branch growth.

\section{Reference}

Keifer, H. H. 1959. Eriophyid studies XXVI. Bull. Calif. Dep. Agric. 47:271-281. 


\section{HOST PLANT INDEX}

Acer spp.

LEPIDOPTERA

Lasi oc ampidae

Malacosoma distria Hübner . . . . . . . 38

Nymphalidae

Nymphalis antiopa Linnaeus . . . . . . . 45

AZnus spp.

COLEOPTERA

Buprestidae

Agrizus spp. . . . . . . . . . . . . . . 4

Dicerca homi Crotch . . . . . . . . 7

Chrysomelidae

Altica ambiens (LeConte).......... 10

Curculionidae

Stemochetus Zapathi (Linnaeus) . . . . . 14

LEPIDOPTERA

Lasiocampidae

Malacosoma distria Hübner . . . . . . . 38

M. califomicum pluviale (Dyar) . . . . . 40

Nymphalidae

Nymphalis antiopa Linnaeus . . . . . . . 45

Amelanchier spp.

COLEOPTERA

Buprestidae

Anthaxia spp. . . . . . . . . . . . . 6

Scolytidae

Chaetophzoeus heterodoxus (Casey) . . . . 16

HOMOPTERA

Diaspididae

Lepidosaphes uImi (Linnaeus) . . . . . . . 26 LEPIDOPTERA

Lasiocampidae

Malacosoma califormicum (Packard) . . . . 40

Nymphalidae

Nymphalis califomica (Boisduva1) . . . . 47 
Arctostaphyzos spp.

COLEOPTERA

Buprestidae Acmaeodera spp. . . . . . . . . . . . 3 AgriZus spp. . . . . . . . . . . . . 4,5 LEP IDOPTERA

Lymantriidae Hemerocampa vetusta gulosa (Boisduva1). . Nymphalidae Nymphalis califomica (Boisduval) . . . .

Saturniidae HemiZeuca eglanterina (Boisduva1) . . . 5 52,53,54

Artemisia spp.

COLEOPTERA

Cerambycidae Crossidius spp. . . . . . . . . . . . 7,8 Triphabda pilosa Blake . . . . . . . . 11 DIPTERA

Tephritidae Eutreta spp. . . . . . . . . . . . . 20 HOMOPTERA

Ortheziidae Orthezia artemisiae Cockerell . . . . . 28 HYMENOPTERA

Formicidae Pogonomyrmex occidentalis (Cresson) . . . 28 P. owyheei Cole . . . . . . . . . . . 28 LEPIDOPTERA

Gelechiidae Aroga websteri Clarke . . . . . . . . . 30

Saturniidae HemiZeuca hera hera (Harris) . . . . . . 52 $H$. nuttaZZi nuttaZZi (Strecker) . . . . . 54

Psychidae Apterona crenulezla (Bruand) . . . . . . 50

Atriplex spp.

LEP IDOPTERA

Psychidae Apterona crenulelza (Bruand) . . . . .

Betula spp.

COLEOPTERA

Curculionidae

Stemochetus Zapathi (Linnaeus) . . . . . 
Betula spp. (con.)

LEPIDOPTERA

Lasiocampidae

MaZacosoma distria Hübner . . . . . . 38

Nymphalidae

Nymphalis antiopa Linnaeus . . . . . .

Ceanothus spp.

COLEOPTERA

Buprestidae

Acmaeodera spp. . . . . . . . . . . 3

Anthaxia spp. . . . . . . . . . . . 6

Dicerca homi Crotch . . . . . . . . 7

LEPIDOPTERA

Lasiocampidae

Malacosoma califomicum Packard . . . . 40

Nymphalidae

Nymphalis califomica (Boisduva1) ... . 47

Saturniidae

HemiZeuca eglanterina (Boisduva1) . . .

53

Cercocarpus spp.

COLEOPTERA

Buprestidae

Acmaeodera spp. . . . . . . . . . . 3

Anthaxia spp. . . . . . . . . . . . 6

Dicerca homi Crotch . . . . . . . 7

Scolytidae

Chaetophzoeus heterodoxus (Casey) . . . 16

LEP IDOPTERA

Ethmiidae

Ethmyia discostrigelza (Chambers) . . . 29

Lasiocampidae

Malacosoma califomicum (Packard) . . . 40

Psychidae

Apterona crenulezla (Bruand) . . . . . 50

Chrysothammus spp.

COLEOPTERA

Buprestidae Agrizus spp. . . . . . . . . . . 4

Cerambycidae Crossidius spp. . . . . . . . . . . 7 DIPTERA

Trirhabda Zewisii Crotch . . . . . .

Tephritidae

Aciurina spp. . . . . . . . . . . 20

Procecidochares spp. . . . . . . . . 20 
Chrysotharmus spp. (con.)

LEPIDOPTERA

Psychidae Apterona crenulezla (Bruand) . . . . . 50

Tortricidae

Synnoma Zynosyrana Walsingham . . . . . 54

Populus spp.

LEPIDOPTERA

Lasiocampidae MaZacosoma distria Hübner . . . . . . . 38 M. califomicum (Packard) . . . . . . 40 Nymphalidae Nymphalis antiopa Linnaeus . . . . . . 45 Saturniidae HemiZeuca nevadensis Stretch . . . . . . 52

Prunus spp.

COLEOPTERA

Buprestidae Anthaxia spp. . . . . . . . . . . . . 6 Dicerca pectorosa LeConte . . . . . . 7 Scolytidae

Chaetophzoeus heterodoxus (Casey) . . . . 16 LEP IDOPTERA

Psychidae Apterona crenulezla (Bruand) . . . . . 50

Saturniidae Hemileuca eglanterina (Boisduva1) . . .

Purshia tridentata (Pursh) DC.

COLEOPTERA

Buprestidae Acmaeodera spp. . . . . . . . . . . . . Anthaxia spp. . . . . . . . . . . . 6 DIPTERA

Cecidomyiidae Mayetiola sp. HEMIPTERA

Pentatomidae

ChZorochroa sayi (Stäl) . . . . . . . HOMOPTERA

Coccidae

Lecanium cerasifex Fitch 
Purshia tridentata (Pursh) DC. (con.)

LEPIDOPTERA

Gelechiidae

Filatima sperryi Clarke ........

Gelechia mandelza Busck. . . . . . .

Geometridae

Anacamptodes clivinaria profanata (Barnes and McDunnough) . . . . . . . . 34

Lasiocampidae

Malacosoma califomicum (Packard) . . .

Lymantriidae

Hemerocampa vetusta gulosa (Boisduva1).

THYSANOPTERA

Thripidae

Frankliniella occidentalis (Pergande). .

ACARINA

Eriophyidae

Aceria krafteZZa Keifer . . . . . . .

Quercus spp.

\section{COLEOPTERA}

Buprestidae

Acmaeodera spp. . . . . . . . . . . Agrizus spp. . . . . . . . . . . .

Anthaxia spp. . . . . . . . . . . .

LEPIDOPTERA

Lasiocampidae

Malacosoma distria Hübner . . . . . .

M. constrictum (Henry Edwards) . . . . 41

Lymantriidae

Hemerocampa vetusta gulosa (Boisduva1) .

Ribes spp.

LEPIDOPTERA

Lasiocampidae

Malacosoma califomicum (Packard) . . .

Rosa spp.

COLEOPTERA

Buprestidae Acmaeodera spp. . . . . . . . . . .

Anthaxia spp.

Curculionidae

Rhynchites bicolor (Fabricius) . . . . HOMOPTERA

Diaspididae

Lepidosaphes uImi (Linnaeus) . . . . . 
Rosa spp. (con.)

LEPIDOPTERA

Lasiocampidae

Malacosoma califomicum (Packard) . . .

Saturniidae

Hemileuca eglanterina (Boisduval) . . .

Salix spp.

COLEOPTERA

Buprestidae

Agrizus spp.

Anthaxia spp.

Chrysomelidae

Altica bimarginata Say . . . . . . . 10

Disonycha latiovittata Hatch . . . . . 11

Curculionidae

Stemochetus Zapathi (Linnaeus) . . . . . 14 HOMOPTERA

Diaspididae

Lepidosaphes uImi (Linnaeus) . . . . . . 26 LEPIDOPTERA

Lasiocampidae

Malacosoma distria Hübner . . . . . . . 38

M. californicum (Packard) . . . . . . . 40

M. califormicum pluviale (Dyar) .... . 40

Lymantriidae

Hemerocampa vetusta gulosa (Boisduval). . 42

Nymphalidae

Nymphalis antiopa Linnaeus . . . . . . 45

N. califormica (Boisduval) . . . . . . . 47

Psychidae

Apterona crenulezla (Bruand) . . . . . 50

Saturniidae

Hemileuca nevadensis Stretch . . . . . 52

H. egZanterina (Boisduval) . . . . . 52,53

Sambucus spp.

COLEOPTERA

Cerambycidae

Desmocerus spp. . . . . . . . . . . . . . 9

Symphoricarpos spp.

LEPIDOPTERA

Saturniidae

Hemileuca hera hera (Harris) . . . . . 53

UImus spp.

LEPIDOPTERA

Nymphalidae

Nymphalis antiopa Linnaeus . . . . . 


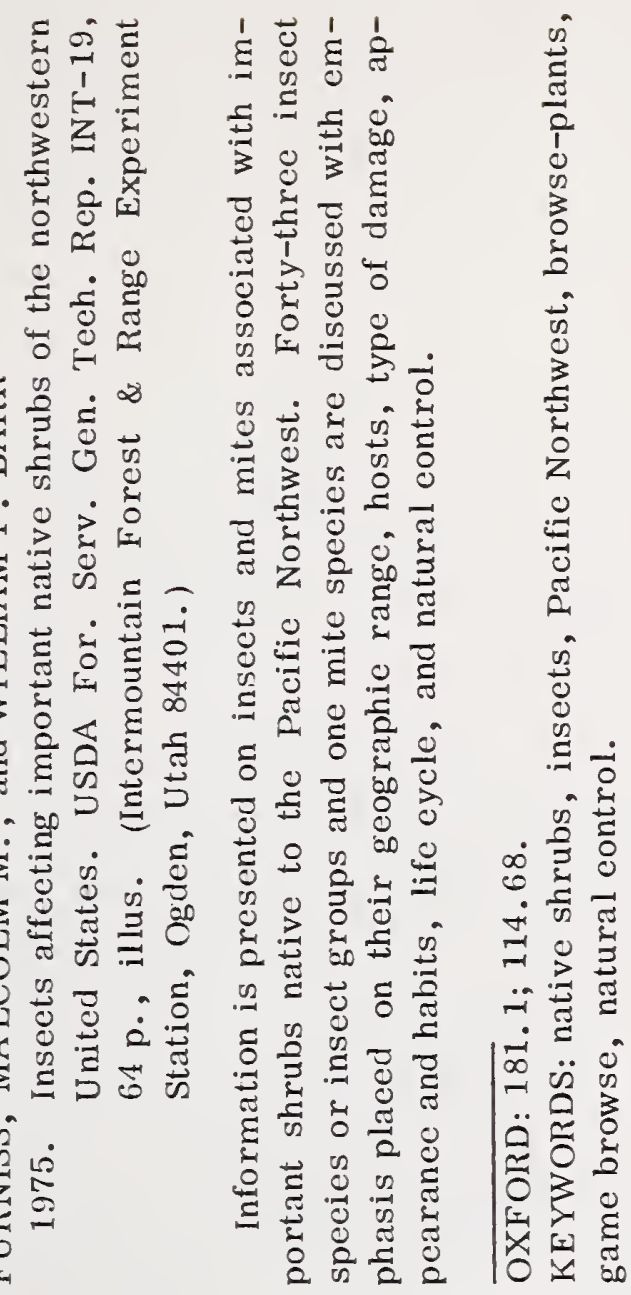

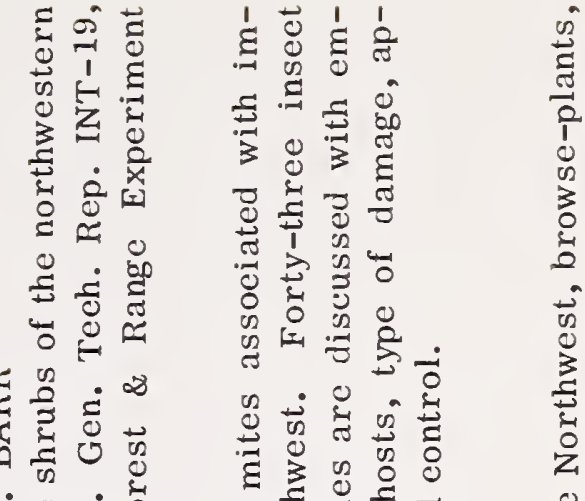

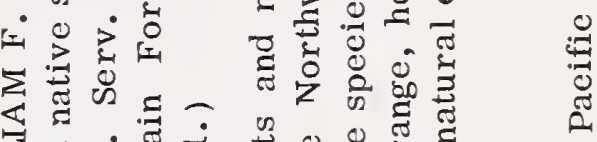

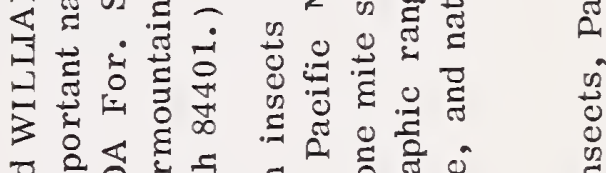

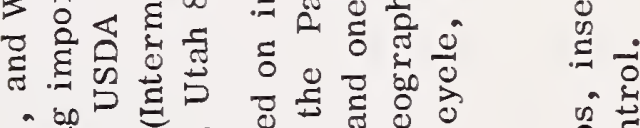

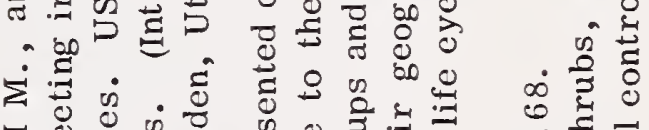

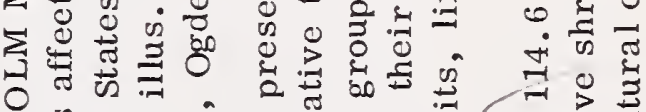

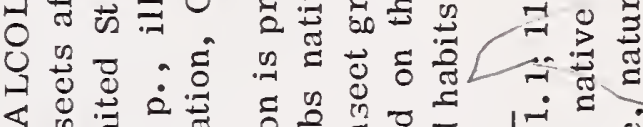

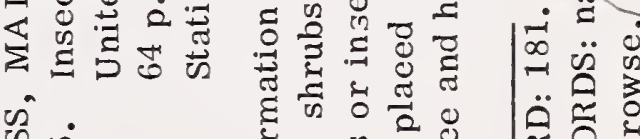

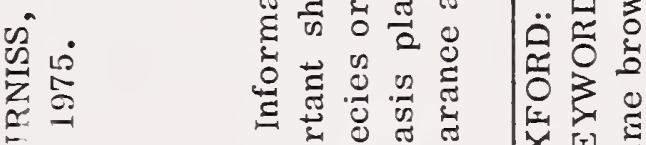
E.

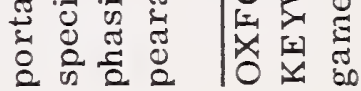

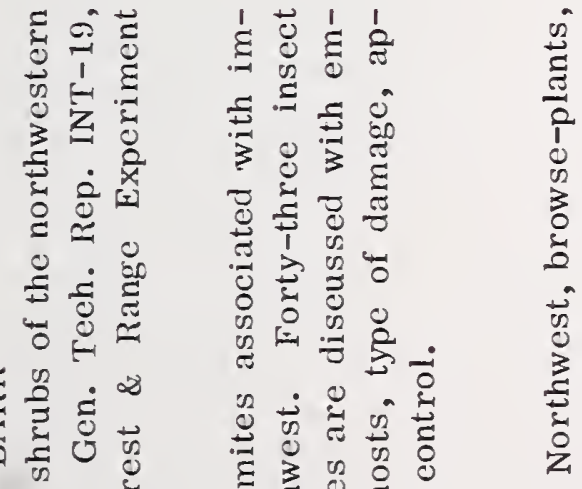

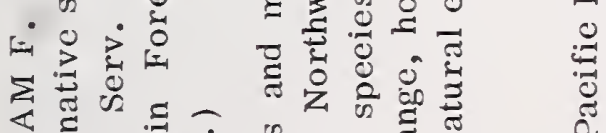

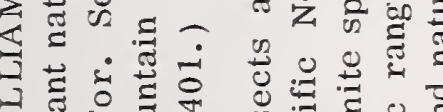

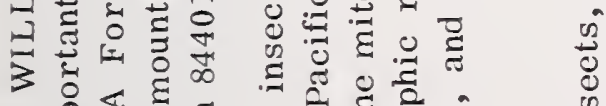

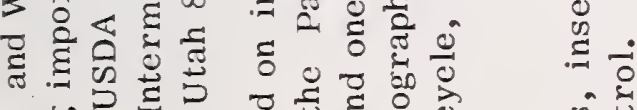

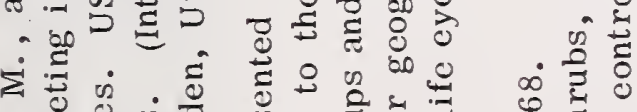

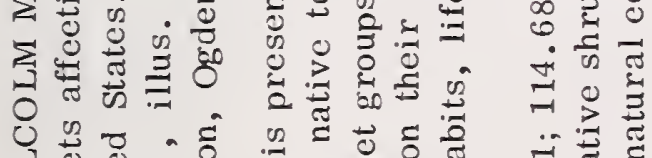

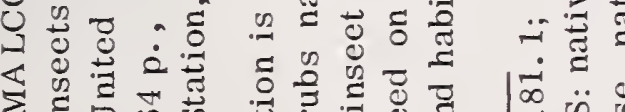

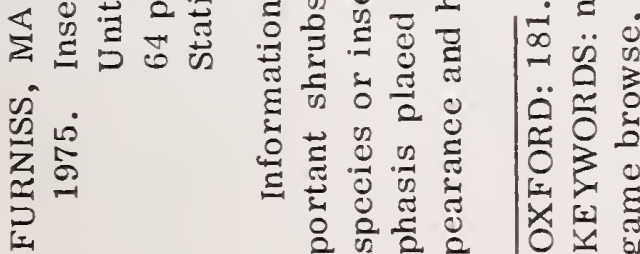

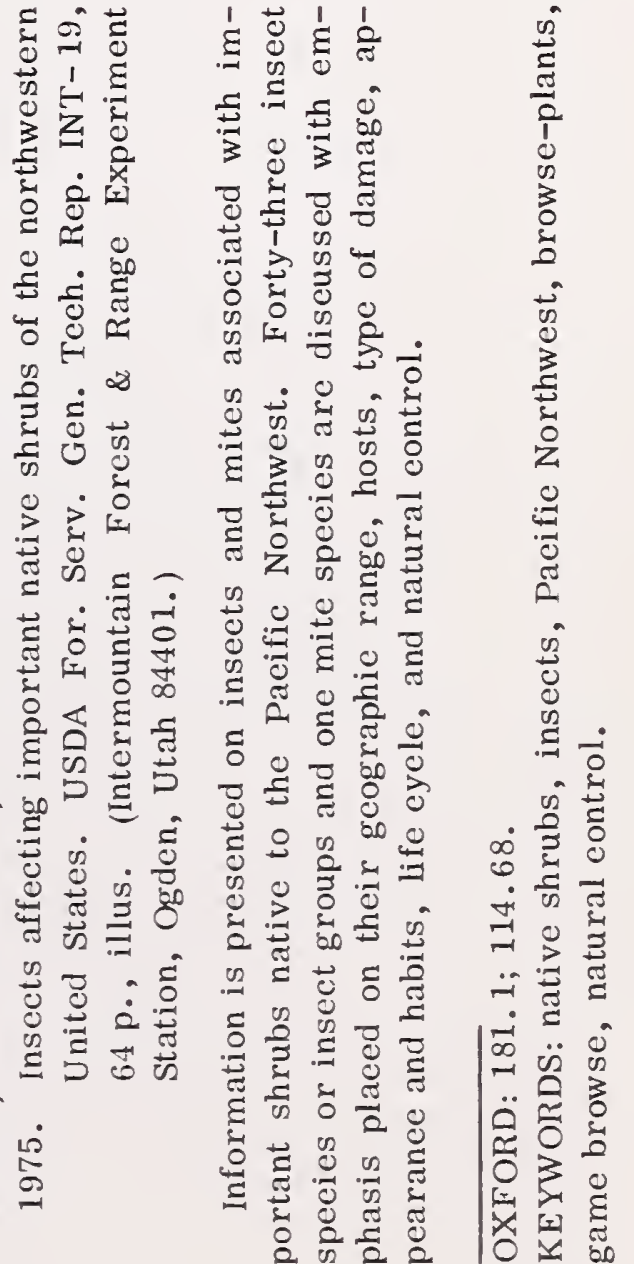



Headquarters for the Intermountain Forest and Range Experiment Station are in Ogden, Utah. Field Research Work Units are maintained in:

\author{
Boise, Idaho \\ Bozeman, Montana (in cooperation with \\ Montana State University) \\ Logan, Utah (in cooperation with Utah \\ State University) \\ Missoula, Montana (in cooperation with \\ University of Montana) \\ Moscow, Idaho (in cooperation with the \\ University of Idaho) \\ Provo, Utah (in cooperation with Brigham \\ Young University) \\ Reno, Nevada (in cooperation with the \\ University of Nevada)
}

\title{
PHOTOS
}

Front Cover: Normal-appearing mountain mahogany shrub, Juniper Mountain, Owyhee Co., Idaho.

Inside Front Cover: Mountain mahogany defoliated by the Zooper, Anacamptodes clivinaria profanata (B. \& MCD.).

Outside Back Cover: Bull elk feeding on serviceberry on winter range, Lochsa River, Idaho.

(Idaho Fish \& Game Department photo by

Thomas A. Leege.) 
